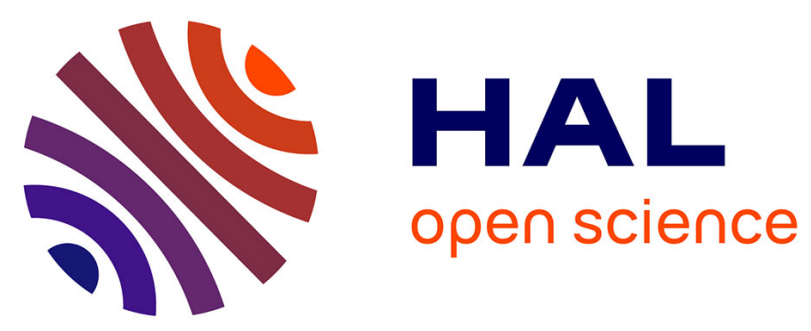

\title{
Bagehot for Beginners: The Making of Lender of Last Resort Operations in the Mid-Nineteenth Century
}

\author{
Vincent Bignon, Marc Flandreau, Stefano Ugolini
}

\section{To cite this version:}

Vincent Bignon, Marc Flandreau, Stefano Ugolini. Bagehot for Beginners: The Making of Lender of Last Resort Operations in the Mid-Nineteenth Century. The Economic History Review, 2012, 65 (2), pp.580-608. 10.1111/j.1468-0289.2011.00606.x . halshs-00844045

\section{HAL Id: halshs-00844045 \\ https://shs.hal.science/halshs-00844045}

Submitted on 30 Mar 2016

HAL is a multi-disciplinary open access archive for the deposit and dissemination of scientific research documents, whether they are published or not. The documents may come from teaching and research institutions in France or abroad, or from public or private research centers.
L'archive ouverte pluridisciplinaire HAL, est destinée au dépôt et à la diffusion de documents scientifiques de niveau recherche, publiés ou non, émanant des établissements d'enseignement et de recherche français ou étrangers, des laboratoires publics ou privés. 


\title{
Bagehot for beginners: \\ the making of lender of last resort operations in the mid-19 ${ }^{\text {th }}$ century ${ }^{1}$
}

\author{
Vincent Bignon, Marc Flandreau, and Stefano Ugolini
}

In this article we develop new tools to survey the development of lending-of-last-resort operations in the mid-19 $9^{\text {th }}$ century. One finding is that free lending and extensive liquidity support against good collateral developed gradually after 1847, and was already a fact of life before Bagehot published Lombard Street. Another is that the extension of the Bank of England's lender-of-last-resort function went along with a reduction of its exposure to default risks, in contrast to accounts that have associated lending of last resort with moral hazard. Finally, we provide a new interpretation of the 'high rates' advocated by Bagehot. We suggest they were meant to prevent banks from freeriding on the safety offered by the central bank, and were aimed at forcing them to march during crises so as to maintain a critical degree of liquidity in the money market.

Keywords: Lending of last resort, Bagehot, Bank of England, financial crises, history of monetary policy.

JEL: E58, G01, N13.

\footnotetext{
1. We are grateful to the Graduate Institute of International and Development Studies in Geneva for support. Marc Flandreau is grateful to Pierre Mirabaud for his contribution to the funding of this project. Stefano Ugolini acknowledges financial support from both the Graduate Institute and Norges Bank. This paper grew out of the Graduate Institute workshop on 'International Money and Finance: Theory and History', that took place during the Fall Semester of 2008. Special thanks are due to several students (in particular Amine Chaieb and Francesco Saccomanni) for the part they took in actively discussing ideas with the authors. The generous comments of Clemens Jobst, three anonymous referees, and the editors are gratefully acknowledged. We are grateful to archivists at the Bank of England and the Bank of France for their help and welcome. Remaining errors and misinterpretation are entirely our own.
} 
The recent sub-prime crisis, described by some observers as a run on banks that manifests itself as a liquidity crisis, has aroused renewed interest for the famous Bagehot's rules encapsulated in a set of principles for successful lending of last resort operations. ${ }^{2}$ These principles were described in Walter Bagehot's Lombard Street, published in 1873, but Bagehot's ideas emerged gradually over the 1860 s in a succession of papers published in the aftermath of the so-called Overend-Gurney crisis of 1866. Bagehot, then editor of The Economist, wrote at a time when recurrent crises in the money market threatened the British economy with financial collapse and dislocation. Problems of the $19^{\text {th }}$-century money market were not unlike those of our own. This market was a place where banks traded short-term debt obligations known then as 'bills' and originating in either commercial or financial transactions. Banks sold their certification of the bills for a fee, and this made them liable for payment. Vast amounts of such securities were exchanged during normal times, but the market seized in panics. A triggering factor could be doubts cast upon the quality of banks' assets as occurred during commodity prices crashes (in 1866, for instance, the collapse of the price of cotton raised doubts on some agents' ability to repay their debts). When this occurred, the inter-bank market dried up, and short-term claims became illiquid. There were fire sales, further liquidations, and bank closures. Just as we saw in 2008, the market then spiralled down in a desperate attempt to bottom out.

Like predecessor writers with The Economist before, Bagehot felt that such emergencies called for the creation of a mechanism, which would support the money market and restore normal operation. He thought that the Bank of England should provide this mechanism and in fact already provided it. More precisely, in the aftermath of the 1866 crisis Bagehot argued that de facto, if not de jure, the Bank of England had begun to acknowledge a role as lender of

\footnotetext{
${ }^{2}$ Gorton, 'The Panic', pp. 2-3.
} 
last resort. The claim, which is now accepted by economic historians, ${ }^{3}$ did upset top Bank of England officials. Thomson Hankey (a Bank director and former governor) countered that, should a policy like that be ever acknowledged, the world would fall apart in an orgy of moral hazard. ${ }^{4}$ The exchange has come to be seen among economic historians and economists of thought as the mother of all controversies on the challenges of lending of last resort, and the debate still rages today among theoreticians.

Bagehot emphasized several principles for successful rescue operations. They included extensive asset-for-cash swaps, with an eye on the quality of the assets that were taken by the central bank, and at high interest rates. He never formally distinguished between these principles, and never said there were three. But subsequent commentators have enshrined this by distinguishing among three principles: 'free lending', use of 'good collateral' only, and reliance on 'penalty rates' - a wording Bagehot never used. As of today, the significance of Bagehot's ideas is still disputed. There has been and there is discussion on the meaning of free lending, good collateral, and high rates.

Bagehot's work can be assessed in different, not mutually exclusive ways. His theory can be discussed with respect to the wording and language actually used in Lombard Street and previous articles published by The Economist, to infer what the author had in mind, as historians of economic ideas do. It can be discussed without reference to what Bagehot had in mind, through the lenses of subsequent monetary theory and models, in an attempt to see which universe(s) support Bagehot's recommendations, as theoreticians do. ${ }^{5}$ Finally, it can be discussed with respect to actual policies and actions that prevailed at the time Bagehot wrote. This guise is the one privileged by economic historians, but economists interested in hypothesis testing and empirical assessment of the performance of lending-of-last-resort

\footnotetext{
3 . Sayers, Bank of England, p. 1, acknowledges that 'when Bagehot wrote Lombard Street in 1873 [...] the Bank had in fact, though not explicitly, accepted its position as the ultimate source of cash in a crisis'.

${ }_{5}^{4}$. Hankey, The principles, pp. 25-38; Bagehot, Lombard Street, pp. 168-87.

5 . We prefer 'subsequent' to 'modern' because, by definition, modern theories always change.
} 
operations should also prefer such an approach. The following pages belong to this third group.

Previous studies of central banks' behaviour during the era when lending of last resort policies were shaped usually start with historical doctrines, and use them to interpret archival evidence. They focus on a number of important qualitative features. With respect to the Bank of England, previous scholars have analyzed the contributing role of important policy doctrines (Banking vs. Currency School), institutional changes (the adoption of the Gold Standard in 1821, and the Bank Charter Act of 1844), debates among bank directors, policy tools, and constraints. ${ }^{6}$ An important matter is the time when the Bank started acknowledging its wider 'public responsibilities' for maintaining money market stability: in the 1830s, for instance, a debate about 'public interest' caused a rift among Bank directors. ${ }^{7}$ There is consensus, among economic historians, that by 1873 the need for the Bank of England to support the market in periods of crises was well recognized, and that the subsequent era marks the heyday of British monetary orthodoxy. ${ }^{8}$

In this article, we adopt a different approach. Our guiding thread is Bagehot's principles, which we seek to translate in quantitative indicators of policy behaviour. Specifically, we have gathered, from primary and secondary sources, material bearing upon the issue of lending of last resort as it presented itself around the mid- $19^{\text {th }}$ century. Working with both the teachings of Bagehot and modern theory on one hand, and with the actual experience of two leading central banks of the time (the Bank of England and the Bank of France) on the other hand, we provide a picture of crisis management in the era of Bagehot. Our goal is narrowly positive: we seek to trace, with the help of novel statistical data, the incorporation of

\footnotetext{
${ }^{6}$. Morier Evans, The commercial crisis; Sayers, Bank of England; Wood, English theories; Morgan, 'Railway investment'; Clapham, The Bank; Mints, A history; Matthews, A study; Fetter, Development; and Goodhart, The evolution. See also the four parliamentary inquiries into the crises of 1847 and 1857: Secret Committee on the Causes (1848), Secret Committee of the House of Lords (1848), Select Committee (1857), and Select Committee (1858).

7 . Collins, 'The Langton Papers', p. 59.

${ }^{8}$. Sayers, Bank of England; Fetter, Development.
} 
Bagehot's rules into the practice of crisis management, focusing on the succession of financial emergencies that hit the monetary and financial systems of the two countries around the mid$19^{\text {th }}$ century. ${ }^{9}$ We are not the first to remark that lending-of-last-resort policy developed $d e$ facto before Bagehot, ${ }^{10}$ but the novelty of this article is that we use modern theoretical concepts to identify relevant tests of central bank's behaviour, we relate our findings explicitly to Bagehot's rules, and we report findings that suggest that the principles encapsulated in Lombard Street were not unknown on the other side of the Channel either. The use of such more precise concepts and measurement, we believe, can go a long way towards improving 'classic' narratives and their occasionally frustrating lack of precision. ${ }^{11}$

The conclusions we reach are the following. First, we find that there was an evolution in the way central banks dealt with crises, from a policy of universal credit rationing before 1850 , to a policy that strongly supported the market by providing unlimited loans, or at least much more generous ones. This evolution, we found, was not limited to England. A similar trend was observed at the Bank of France, and the chronology, to the extent that comparison across crises is legitimate, supports the notion of a general pan-European transformation. This similarity is intriguing and suggests that at one broad level, the development of lending-oflast-resort operations does not owe much to country-specific factors, nor to specific exchange rate regimes such as the one that was in place in Britain since 1821. Our findings suggest that the Gold Standard and the Act of Peel may have less to do with the transformation we observe than earlier research has suggested.

Second, we find that, contrary to a popular view in both traditional and more recent discussions, the extension of lending of last resort did not result in increased moral hazard.

\footnotetext{
9 . Focus on long-run trends in crisis management does abstract from short-term fluctuations in policy views and controversies on the principles of crisis lending. For instance, King, History, pp. 193-216, devotes a long discussion to controversies over crisis policy reversals after 1858, eventually laid to rest in the midst of the 1866 crisis.

${ }^{10}$. Sayers, Bank of England; Collins, 'The Bank'.

11 . For instance, compare King, History, p. 166, with the findings summarized in this article.
} 
This may appear as something of a puzzle. We explain it by noting that the extension of liquidity support was not accompanied with relaxation of prudential standards - much to the contrary. Using material from the Bank of England Archive, we discover that at the time lending-of-last-resort policies emerged, there was a receding amount of problem bills, suggesting that standards were being tightened, not relaxed. The standard criticism of Bagehot's rule as an encouragement to rogue behaviour is thus inadequate and misleading from an historical vantage point. We note that the making of lending-of-last-resort operations was parallel to the making of a high-quality London bill market, certified by prestigious merchant banks and made liquid by the Bank of England. The extent to which this helped establish the London bill as the supreme instrument in the international money market cannot be discounted.

Third, our characterization of lending-of-last-resort policy - as proceeding from a robust knowledge of the operation of the money market by the central bank, and from the use of prophylactic devices during intercourse between the bank and the market - sheds a new light on the third and less understood of Bagehot's three sacred principles. We suggest that the 'high' rates Bagehot recommended may be understood as a fine on bankers' reluctance to lend to one another - or equivalently, as an encouragement to make use of the information they have on one another rather than seek the safety of the Bank, for this may result in a complete collapse of inter-bank lending and destruction of information. This conclusion is interesting given the difficulties that central banks have recently met in restoring confidence by lowering interest rates and becoming what one observer has called the 'money market makers of last resort'. ${ }^{12}$ When bank deposits at the central bank earn interest and when the interest rate on new lending is low, the incentives for inter-bank lending do disappear and

\footnotetext{
${ }^{12}$. Willem Buiter, 'The central bank as a market maker of last resort', Maverecon, 12 August 2007.
} 
banks are happy to let the money market be fully internalized by the central bank. But this, we suggest, stands in the way of a revival of the money market.

The remainder of the article is organized as follows. Section I provides a brief survey of the Bagehotian legacy in modern lending-of-last-resort theory, outlining central themes. Section II describes the historical background, outlining the operation of the money market and the relation it had with the central bank in Britain in the mid- $19^{\text {th }}$ century. Section III discusses free lending. Section IV discusses collateral. Section V discusses moral hazard. Section VI discusses penalty rates. Section VII concludes.

\section{I}

In order to explain why there should be lending of last resort, economists first explain why there should be panics. As a result, the forms taken by lending of last resort in the literature owe a lot to the way panics arise in economic models. Douglas Diamond and Philip Dybvig were the first to formalize the occurrence of bank runs as a possible outcome. ${ }^{13}$ The run they imagine emerges because agents go on the 'wrong' equilibrium, thus producing a selffulfilling collapse which turns out to be rational ex post. ${ }^{14}$ Some papers have criticized the underlying hypotheses of such models, showing that they are quite contingent to the set of contracts agents are allowed to make. ${ }^{15}$ Gary Gorton has studied the panics of the U.S.

\footnotetext{
13. Diamond and Dybvig, 'Bank runs'. More recent variants include Cooper and Ross, 'Bank runs', and Green and Lin, 'Implementing'. A variant of the Diamond and Dybvig explanation of bank run in terms of sunspots is provided by Postlewaite and Vives, 'Bank runs', introducing information asymmetry and uncertainty about the fundamentals.

${ }^{14}$. In this perspective, bank runs are described as a result of a 'psychological' phenomenon (sunspots), not of poor financial management.

15. Wallace, 'Another attempt'; Green and Lin, 'Implementing'; Andolfatto, Nosal, and Wallace, 'The role'.
} 
National Banking Era and concluded that crises were predicted by indicators of the business cycle, suggesting that self-fulfilling bank runs are empirically irrelevant. ${ }^{16}$

Charles Goodhart has emphasized the role of balance-sheet mismatches - which brings more real-life insights to the analysis. ${ }^{17}$ In his view, banks are intermediaries that use shortterm nominal deposits (redeemable on demand) to finance long-term projects. Since the price of deposits is fixed, it is not possible to adjust to an asset-side shock by devaluing the liability side of the balance. Given this, depositors understand that some of them will not be reimbursed in the event of a run. Bank runs occur because the quicker agents remove deposits, the more likely they are (individually) to get their money back. But a run impacts negatively the economic welfare of those depositors who do not get reimbursed and of those debtors who get liquidated. In this context, Goodhart argues that 'a Central Bank will aim to prevent, and, if that fails, to recycle such flows - subject to such safeguards as it can achieve to limit moral hazard and to penalize inadequate or improper managerial behaviour' ${ }^{18}$ Economists have remarked that other institutions can fulfil the same purpose. For instance, Gary Gorton and Lixin Huang have shown that liquidity provision during crisis can be ran by the private sector, through a coalition of banks issuing redeemable claims backed by the assets of all member banks. ${ }^{19}$ A governmental or state-owned central bank (which neither the Bank of England nor the Bank of France were in the $19^{\text {th }}$ century) is only useful if the government has much more resources than private agents, or if other costs to panics are considered - for instance, if panic disrupts lending to sound corporations or threatens the disruption of the national payment system.

\footnotetext{
16 . Gorton, 'Banking panics'. This result has been formalized in the literature on information-based bank runs: Chari and Jagannathan, 'Banking panics'; Jacklin and Bhattacharya, 'Distinguishing panics'; Allen and Gale, 'Optimal financial crises'.

17 . Goodhart, 'Why do banks'.

18 . Ibid., p. 88.

19 . Gorton and Huang, 'Bank panics'. In their model, bank panics (i.e. runs on deposits) are rational in that they constitute a way for uninformed depositors to monitor banks' behavior.
} 
Other interesting issues that have been considered by theoreticians include the channel through which the central bank provides help to the banking system, and the price at which emergency liquidity is provided. It is fair to say that the answer to these questions critically depends on the environment in which banks operate. Marvin Goodfriend and Robert King dismiss the role of central banks in allocating funds to illiquid banks. ${ }^{20}$ They argue that in well-functioning financial markets, a solvent institution cannot be illiquid. They conclude that the only role for central banks is providing the market with the aggregate liquidity and let the market distribute it to individual banks. In other words, open-market operations are useful, but the discount window or targeting of help to specific banks is redundant or nefarious. Yet Rafael Repullo notes that the same informational reasons making banks' loans illiquid in aggregate can imply that one individual bank may not be able to borrow the required funds from the others. ${ }^{21}$ This may be amplified by strategic considerations. In some situations, some participants to the money market are unwilling to lend to others, as this may weaken competitors - differently said, banks may seek to amplify other banks' liquidity problems to force their liquidation. This can arise when some assets are bank-specific, which means that the market for these is easy to manipulate. ${ }^{22}$ The sub-prime crisis provides instances where accusations of disingenuous banks' refusals to lend to one another were made. Since the central bank is involved in periodic operations with commercial banks, it can be in a favourable position to monitor or lend to a given banking establishment. ${ }^{23}$

Another important issue is whether a discount window stimulates moral hazard. Antoine Martin suggests that a lender of last resort does not encourage risk taking, provided that it does not suffer from a severe informational disadvantage with respect to commercial banks'

\footnotetext{
${ }^{20}$. Goodfriend and King, 'Financial deregulation'. Also see Bordo, 'The lender'; Kaufman, 'Lender'; and Schwartz, 'The misuse'.

${ }^{21}$. Repullo, 'Who should act', p. 580.

${ }^{22}$. Acharya, Gromb, and Yorulmazer, 'Imperfect competition'.

23 . Rochet and Vives, 'Coordination failures'.
} 
activities. $^{24}$ This result is also obtained if the central bank has priority over the assets of the banks it lends to.

The question of the interest rate at which the central bank should lend has attracted considerable interest. In sharp contrast with Bagehot's recommended policy of lending at high rates, the theoretical literature has generally argued in favour of lending at a zero interest rate. $^{25}$ The reason is that, in models where the rationale for a lender of last resort is a coordination problem preventing commercial banks from lending to one another other, the interest rate of the discount window should be set at a sufficiently low rate to guarantee the continuation of liquidity provision. It is also likely that, following Friedman and Schwartz's critique of the Fed's handling of the aftermath of the 1929 stock market $\mathrm{crash}^{26}{ }^{2}$ the consensus has moved to the general notion that in the event of crises central banks should swamp the market with money.

Some authors, however, have rationalized a policy for high interest rates. At a broad level, a credible high rate in times of crisis may make banks reluctant to take risks as this will increase the cost of emergency refinancing. ${ }^{27}$ Christopher Sleet and Bruce Smith provide an example in which the central bank must set its rate at a very high level in order to compensate for the losses it may incur from bailing out insolvent banks. Technically, the social return to rescuing a distressed banking system (through the operation of a discount window at a very high rate) is then high enough to compensate for increased moral hazard. ${ }^{28}$ Xavier Freixas, Bruno Parigi, and Jean-Charles Rochet also suggest that a penalty rate can be optimal when

\footnotetext{
24. Martin, 'Liquidity provision'.

${ }^{25}$ Champ, Smith, and Williamson, 'Currency elasticity'; Freeman, 'The payments system'; Green, 'Repurchase agreements'; Allen and Gale, 'Optimal financial crises'; Williamson, 'Discount window lending'; Antinolfi, Huybens, and Keister, 'Monetary stability'; Martin, 'Liquidity provision'; Rochet and Vives, 'Coordination failures'; Williamson, 'Limited participation'.

${ }^{26}$. Friedman and Schwartz, A monetary history.

27 . Sheng, 'Role'; Summers, 'Clearing'.

28 . Sleet and Smith, 'Deposit insurance'. This can actually be taken as a suggestion that Bagehot's rationale is fragile. If there are parameters for which lending of last resort at high rates is profitable, then there must be others for which it is not. The authors also provide an example in which the advantage of financing risky operations does not outweigh the cost of liquidation and foreclosure.
} 
the main source of banks moral hazard lies in faulty ex-ante screening of borrowers. A penalty rate reduces this kind of risk taking, as it discourages insolvent banks from appealing to refinancing facilities. ${ }^{29}$ Finally, in a different vein, Antoine Martin shows that a penalty rate can help to allocate central bank's funds to the most needy banks, as this eliminates the incentive for sound lenders to withdraw too early from the market. ${ }^{30}$

\section{II}

The simplest way to understand central bank operations during the mid- $19^{\text {th }}$ century is to start from a description of the money market. Money markets in Europe, unlike in the U.S., operated along common general principles. The staple instrument of these markets was the bill of exchange. Drawn by one agent, countersigned by another, it bore two signatures and could then be traded - or, in the language of the time, 'discounted'. Through this mechanism, unknown houses could draw on the credit of banks commanding respect and credibility on the marketplace. The operation was known as 'accepting', and the prime instruments in this market were the 'acceptances' - as accepted bills were called. Leading 'merchant banks' (as modern investment banks were called in England) accepted huge amounts of bills annually in a manner that bears similarities to the modern 'originate and distribute' model. On the one hand, the banker with a prestigious name earned a fee from accepting the instrument; on the other hand, the debtor earned the spread between the interest rate at which he would have 
been granted credit on his own name and the lower one at which the claim, once accepted by a prestigious banker, could be discounted on the market. ${ }^{31}$

The accepting banker bore responsibility for payment. So were also all subsequent discounters (purchasers) who had bought the bill from the original debtor, endorsed it, and then put it back into circulation. If the acceptor failed, endorsers were called in. In some legal systems, the holder of the bill could call in any name in the list of endorsers, leaving it up to the summoned party to recoup their claim. In others, creditors had to go by order of endorsement with the acceptor first, the last endorser second, and so on, following backwards the chronology of endorsements.

Bills were packaged in aggregate instruments called 'parcels' that could be swapped across the market. Parcels bore the guarantee of the packer. In some places, such as in England, the practice of bill broking developed. Banks needing cash and banks having surplus of cash traded positions on a daily basis through the agency of bill brokers. Bill brokers thus lived from surplus funds from the banking system, which were taken on call and invested in parcels and bills. The market rate was the rate at which the market for prime bills would clear. Tensions in the money market were therefore eventually reflected in higher call rates. London appears to have been one place where this mechanism was most refined and perfected. In other places, such as Paris, the inter-bank market was less active and apparently less fluid, although a full study of the long-run evolution of this market is yet to be made. ${ }^{32}$ Prime paper, accepted by the Haute Banque (France's equivalent to London's most prestigious merchant banks), was said to be always negotiated on favourable terms and to find ready buyers.

\footnotetext{
31. For a description of the workings of the $19^{\text {th }}$-century bill market, see e.g. Gilbart, A practical treatise; Seyd, Bullion; Withers, The meaning.

32 . Haupt, Arbitrages, states that towards the late $19^{\text {th }}$ century bill brokers in Paris were used as intermediaries to trade parcels across banks in an over-the-counter inter-bank market.
} 
To a not inconsiderable extent, central bank operations were not significantly different from those of other regular commercial banks. ${ }^{33}$ 'Banks of issue', as they were initially known (i.e. privileged banks with a more or less exclusive right to issue and circulate bank notes), got involved in both originating (accepting) and discounting (purchasing) bills. For instance, conventional accounts of the policies of the Bank of France claim that its provincial branches or comptoirs accepted bills in which the Paris headquarters was later invested. In this case, the branch was both the acceptor and the discounter, with the implication that the primary purpose was commercial lending. ${ }^{34}$

Towards the middle of the $19^{\text {th }}$ century, central banks had a broad clientele of customers who were eligible for discount facilities. These customers were not only or even primarily bankers. Among Bank of England's 'discount accounts' active around 1850, one finds such names as 'Blackwell, publishers'. ${ }^{35}$ Some authors argue that as time passed, the activity of banks of issue became more focused on discounting banks' paper. Several central banks retained a substantial commercial activity and some (such as the Bank of France or the Austro-Hungarian Bank) even expanded it, creating more branches. ${ }^{36}$ In all cases central banks did retain their commercial activities, but this must be separated from crisis lending. Richard Sayers explains that from 1878 onwards the Bank declared itself bound not to adhere to its official rate when discounting fine bills for its regular customers, and started commercial ('normal times') discounting below the 'Bank rate' which thus became the rate at which the Bank would 'help the market in a crisis'. ${ }^{37}$

\footnotetext{
33 . Goodhart, The evolution.

34. Plessis, Histoires.

35 . Bank of England Archive, C29/13: 'Rating Book, showing each discounter's credit limit'. More generally, see C29/11 to 18 for $1827,1845,1850,1856,1860,1874$ and 1882, the later being updated until the 1920s.

36 . Jobst, 'Gouverner'.

37. Sayers, Bank of England, p. 4. See also King, History, pp. 291-6. Bank of England Archive C30/3 provides statistics on discounts below the bank rate.
} 
Figure 1 shows the evolution of the number of discounters at the Bank of England between 1844 and $1914 .^{38}$ After an initial increase (the number of discounters reaches a peak of more than 1400 in 1847), figures began to decline steadily - they were below 400 after 1900 . Pending the construction of rigorous statistics for the demographics of Bank of England's discounters, we get a sense of what was going on by leafing through the ledgers. Apart from a contraction coming from mergers and bank closures, a large fraction of the accounts that closed down were non-banks, supporting the conventional wisdom of a gradual evolution of the Bank of England towards dealing with specialist intermediaries.

Discounting of bills was an outright purchase in the market. To the extent the bill was paid at maturity, there were no more interactions between the holder and the discounter, previous endorsers, or the primary debtor. Only when a bill was returned unpaid from the acceptor did the holder turn to the other intermediaries - first and foremost, the discounter. Thus bills discounting was 'secured' by the credit of the acceptor and discounter. As a result, the credit of the discounter was subjected to severe scrutiny. One had to be 'introduced' to the Bank of England, and its books bear a mention of the person who had fathered each account. Some names appear frequently: insiders of the Bank of England (governors, members of the board), prominent merchant bankers, etc., supporting the view that discounters belonged to a club ${ }^{39}$.

But a good introduction was not enough. Sometimes, especially for private banks where liability was unlimited, knowledge that the discounter owned some valuable estate was considered a sufficient guarantee. However, evidence on unpaid bills shows that a variety of additional securities were sometimes required as a pledge against discounts. Discounters could be asked to issue promissory notes on themselves for a larger amount than the bills to

\footnotetext{
${ }^{38}$. Bank of England Archive C30/3. The source is silent as to the precise significance of this concept and to how much it may differ from the number of customers that actually borrowed from the Bank (as in fact many accounts were dormant). In principle, however, the two notions should be related to one another.

39. This is supported by inspection of Bank of England Archive C29/4, Discount Office: 'List of discounters, giving name, trade, and by whom introduced [...], 1804-1899'. Flandreau and Ugolini, 'Where it all began', provide a discussion.
} 
be discounted, and deposit them as collateral. With these notes, the discounter recognized himself as liable towards the Bank of England should the discounted bill not be paid. Registers provide indications of limits per discounter.

Another type of operation consisted of advances, comparable to today's 'repos': a security was pledged at the bank and then repurchased by the debtor at a given date. One difference between modern repos and $19^{\text {th }}$-century 'advances', however, is that the amount of security taken was more substantial. Central banks could take large haircuts, so that if the loan was defaulted upon and the security left with the bank, the exposure would be minimal. This may have been adequate compensation for risk when the collateral was a financial security subjected to large price volatility, but is also observable in the Bank of France's fully secured business of lending on gold and silver. ${ }^{40}$

Figure 1 about here.

\section{III}

The first of the three Bagehotian 'rules' is the most straightforward. From both text and context, 'free lending' is an argument about credit rationing. It is obvious from many parts of Lombard Street, for instance in those passages in which Bagehot blames the timidity of the Bank of England during earlier panics. ${ }^{41}$ This interpretation is also consistent with the coverage of Bank of England operations that The Economist gave during the crisis of 1847 (at a time when Bagehot was not yet involved). The main accusation the newspaper made during

\footnotetext{
${ }^{40}$. Flandreau, The glitter, pp. 230-1, discusses the terms and conditions of collateralized loans on gold and silver at the Bank of France.

${ }^{41}$. Bagehot, Lombard Street, pp. 64-66.
} 
the crisis was that the Bank engaged in policies that discriminated against longer bills through both price and non-price mechanisms. Price mechanisms took the form of higher discount rates for longer maturities. Non-price ones were outright credit rationing. As The Economist complained, the Bank had refused to 'discount any but extremely short dated paper'. As a result, 'the minimum rate of the Bank of England is no longer any rule or criterion; [...] the Bank nominally maintains a rate of discount which, practically, does not exist' ${ }^{42}$ Similar statements would be frequently read until the crisis finally reached its apex and, on 25 October, the Act of 1844 suspended to permit the Bank to do away with its statutory constraints and lend more generously.

The news published in The Economist reflected information that was available in the market, which itself learnt from the Bank through daily interactions with its discount window. The rapidity through which news about rationing were known to the public and divulged by The Economist is notable. For instance, internal Bank of England sources indicate that on 15 April 'the governors in their instructions to the committee of Daily Waiting in fixing the rate of discount on bills of exchange, be recommended to take into consideration the periods the bills have to run - as also the position of the accounts of the discounters etc.' ${ }^{43}$ Two days later, on 17 April, The Economist reported: 'The Bank, by omitting any mention of time in the weekly notice, has relieved itself from an implied obligation to take bills of any special date, and the consequence has been, that they have rejected large quantities of paper falling due after this month'. The policies of the Bank were thus fairly transparent to the market. This is not surprising, since credit rationing had a direct effect on discounters who were turned down. Their disappointment found its way in the press.

\footnotetext{
42. The Economist, 24 April 1847. Or again some days later, the newspaper argued that "in the early part of the week the Bank discounted first class May and June bills at 5.5\%, and bills due early in July at $6 \%$; but the applications were greater than even the increased scale of business enabled the Bank to comply with, and there have, therefore, been a large amount of bills refused", The Economist, 1 May 1847

${ }^{43}$. Insider Bank of England memorandum filed under November 1857 and reviewing (with some omissions) the Bank's policy regarding the maturity of the bills it discounted from 1821. Bank of England Archive, G15/97, 'Memorandum in regard to the échéance of bills discounted at the Bank, filed under November 1857' ('échéance' is French for 'maturity').
} 
Our inference from this is that information available on the market is a proper way to infer what is happening inside the Bank. This suggests a test of credit rationing. If a central bank does behave as a lender of last resort, its interest rate (for any given quality) ought to be always above, or equal to, the market rate (for the same quality). The same asset cannot have two different prices in a well-functioning market - otherwise, an arbitrage would be feasible. Suppose that this were the case. Then, rational agents would prefer to discount their bills at the central bank rather than at higher market rates. And thus it is that the central bank's rate cannot be lower than the rate prevailing in 'Lombard Street' (the market rate). ${ }^{44}$ A simple test of whether the central bank behaves like a lender of last resort (which formally tests whether we can accept the null that the Bank does not ration credit) is to compare the market rate and the bank rate: If the bank rate is below the market rate, we reject the null that the central bank is a lender of last resort (accept the alternative that there is credit rationing). ${ }^{45}$

Using the descriptions and information from The Economist, we have collected data on both the market rate and the bank rate for three-month bills during the three main crises of the mid- $19^{\text {th }}$ century, viz. in 1847,1857 and $1866 .{ }^{46}$ The magazine does enable distinguishing

\footnotetext{
44. By contrast King, History, pp. 109-17, argues that a Bank rate below the market is indicative of the Bank's competing against the market. This needs not be inconsistent with our interpretation, since a central bank competing against the market may be tempted to ration competitors (see Goodhart, The evolution, for a discussion of the conflict of interest that had to be addressed for modern central banking to emerge). However, King does miss the important implication that a lender of last resort performing free lending cannot have its rate below that of competitors. Relying on official testimonies, he fails to see that it is just not possible that 'the practice of placing absolute restrictions upon discounts in times of pressure [...] was virtually abandoned [after 1844]'.

45. An hastened comparison with nowadays' situation, in which market rates fluctuate around and thus occasionally above the official bank rate, should not delude the reader. In the $19^{\text {th }}$ century, by offering unlimited access to central bank funds at a publicly set price, central banks' standing facilities (the discount window) provided an upper limit to market interest rate. Today, the official central bank rate is not the rate on a standing facility and thereby not an upper bound for market rates, but (technically) the rate at which minimum reserves are remunerated. A standing facility analogous to the $19^{\text {th }}$-century discount window still exists today, but the interest rate on this facility is set well above the official bank rate (typically +100 basis point). See Bindseil, Monetary policy implementation, for an overview.

${ }^{46}$. Building on Collins, 'The Langdon Papers', one might hypothesize that the adoption of the Bank Charter Act of 1844 caused reversal of policies in the 1840s, so that the Bank of England's behaviour in 1857 would have been a mere return to earlier practices. However, data for bank and market rates published by Wood, English theories, suggest that the crisis of 1847 displayed a similar pattern to those of $1825,1836-7$, and 1839-40 during all of which the market rate climbed above the bank rate.
} 
between two maturities, 'long' and 'short' - and for 1847, 'very short' as well. ${ }^{47}$ The test is to compute the difference between the market rate and the bank rate for a given maturity, and to see whether the result is positive (reject the hypothesis that central bank is a lender of last resort). The outcome is shown in Figures 2 a to c. As can be seen, the data strongly suggest that there was rampant credit rationing during the crisis of 1847 , but it receded afterwards. There is a brief violation in 1857, just before the suspension of the Act. During the crisis of 1866 , no credit rationing is visible.

Figures $2 \mathrm{a}, 2 \mathrm{~b}$, and $2 \mathrm{c}$ about here.

Another way to look at discrimination by the central bank (the opposite of free lending) is to explore the relation between applications for discounts and the actual amounts discounted. The Bank of England Archive contains some evidence enabling to document this for the three crisis years. ${ }^{48}$ It consists of reported monthly total applications and actual discounts, shown in Figures $3 \mathrm{a}$ to c. Total rejections rates suggest a change of behaviour between $1847(11 \%)$ on the one hand, and 1857 and 1866 on the other hand (3.5 and 4.5\% respectively). Moreover, the rejection rate at the peak of the crisis declined over time. It is $16 \%$ in October $1847,7 \%$ in November 1857 and 3.5\% only in May 1866. Such figures would not prove anything by themselves, as a lot of unobservable strategic behaviour was probably at work. Agents, understanding that the Bank would not discount them anyway, might have reduced their applications later on. However, in conjunction with the earlier evidence from price data on the

\footnotetext{
47. The articles run by the magazine and the data it published can be used to reconstruct the succession of policy changes. We have organized this material in Figure 2a. We report, according to The Economist, the spread between market and bank of rates for 'very short' (a few days), 'short' (a couple of weeks), and 'long' (fortyfive to ninety days) bills. If we are to believe the reports from The Economist, use of price and non-price discrimination against long term bills were correlated with one another.

${ }^{48}$. Bank of England Archive, Discount Office, Daily Registers, C28/7, C28/17, and C28/26.
} 
lack of credit rationing during later periods, the evidence on rejection rates provides strong suspicion that a revolution was going on.

Reinforcing evidence can be found by observing the increase in discounts at the peak of the crisis. It becomes much stronger as time goes by. The average ratio between the amount of discounts during non-crisis months and the crisis month is $54 \%$ in $1847,38 \%$ in 1857 , and $23 \%$ only in 1866 . Over time, therefore, agents were learning that the Bank was becoming more generous and accordingly they increased their applications, which were generally received favourably. The evidence strongly suggests there was an increase in the liberality and elasticity in the supply of credit by the Bank of England during financial emergencies.

Figures $3 \mathrm{a}, 3 \mathrm{~b}$, and $3 \mathrm{c}$ about here

The last bit of evidence we report here has to do with what was happening on the other side of the Channel at about the same time. France went through three major crises: she experienced more or less the same financial turmoil as England and the rest of the world in 1847-8 and 1857, avoided the problems of 1866, but experienced a crisis of its own in 1881-2. We have collected material for the setting of the interest rate, looking for evidence of maturity rationing. Interest rate data for the Bank of France are from Auguste Vitu's textbook, which provides the maximum maturity and, for each maturity, the corresponding interest rate. ${ }^{49}$ As can be seen in Table 1, during the first two crises, the Bank of France reduced the maximum maturity and charged higher interest rates for longer bills. We recognize the tactics already observed at the Bank of England.

Table 1 about here

\footnotetext{
49 . Vitu, Guide financier, p. 305.
} 
To track the evolution of the policies of the Bank of France, we now replicate the test performed for the Bank of England discount rate and compare the Bank of France rate for prime three-month bills with the market rate for similar instruments. Until 1861, when The Economist started reporting it, there is no reliable series for the Paris inter-bank market. Explorations in bank archives have never managed to produce a continuous series for this rate for early periods, although correspondence in merchant bank archives establishes conclusively that a Paris money market and a Paris market rate did exist. As a result, the proper construction of the relevant series awaits its historian. ${ }^{50}$ To sort this out, we have relied on a trick, which uses the London price for swaps of spot and time deposits in Paris (the socalled exchange rate for sight and three-month bills) to infer a measure for the 'shadow price' of money in Paris. ${ }^{51}$ This is used for the years before which the material in The Economist is available. The indications for the early phase are thus estimates only, although probably reasonable ones (when the 'true' series becomes available it turns out to be fairly close to the estimated one). ${ }^{52}$ This must be borne in mind since, by contrast, the material we had for the London money market is the actual interest rate that was quoted in real transactions.

The outcome of this exercise is presented in Figure 4. Rather than focusing specifically on crisis years, we present the long-run evolution of both the Bank of France rate and the money market rate, estimated (pre-1861) or measured (afterwards). As can be seen, credit rationing and violation of the Bank of France 'ceiling' are routine events in the first part of the century. In effect, the Bank of France initially behaves as if it had an interest rate target of $4 \%$ and lets the market rate hover above it from time to time. The crisis of 1848 exhibits some spectacular violations, which are not unlike what we observed for the Bank of England. The lack of a

\footnotetext{
50 . Data for market interest rates are only available following the boom of joint-stock deposit banks, which by nature or inclination have typically left more systematic statistical material in their archives than the private merchant banks.

${ }_{52}^{51}$. Flandreau et al., 'The bell jar'.

52 . The results of this exercise are reported by Ugolini, 'The international monetary system', p. 26.
} 
point estimate for the market interest rate in some months is itself indicative of credit rationing. It means that traders in London stopped buying prime bills payable in Paris: yet this would have not occurred, had the Bank of France stood willing to discount unlimited amount of these. Finally, we see that violations decline over time. There are still some in 1857 , but just like what we saw earlier for the Bank of England, violations tends to recede over time. In the end, the Bank of England and the Bank of France appear to have obeyed the same rules of motion. $^{53}$

Figure 4 about here

\section{IV}

The question of 'good collaterals' - those eligible for advances - is the next we examine. One difficulty with dealing with it is that there is circularity in the effects of successful lending of last resort: ex post, those who deserve to be saved are saved, and that is how we know they were deserving. This issue is the same as that of the perplexingly thin line between insolvency and illiquidity. In this section, we are interested in determining not what ought to have been a good security, but what contemporaries perceived to be a good security - and as a result, how good securities became such.

In the case of bills, good collateral meant bills bearing prestigious names as acceptors, bills brought in by sound discounters, or bills on which serious guarantees were taken. Noting this, however, hardly closes the matter, and we shall return to it in Section V. In the case of collateralized loans (or repos-cum-haircut operations) known as 'advances', the list of eligible

\footnotetext{
53. According to Flandreau, The glitter, after 1857 a greater degree of freedom was granted to the Bank of France through the abolition of usury laws; from that point on, the Bank stopped resorting to credit rationing.
} 
securities changed over time. ${ }^{54}$ Figure 5 shows (for London) the amounts discounted and the total advanced to the market on an annual basis since 1844 (counterpart figures for the branches of the Bank of England could not be found). As can be seen, advances increased dramatically during crises, as did bills.

Figure 5 about here

And thus, we may wonder, what were the good securities on which a proper central bank would be expected to lend freely? According to Bagehot, 'standard' securities were British government (and some colonial) bonds. ${ }^{55}$ Consistently, we suggest here an original test of the evolution of lending-of-last-resort operations that uses the good collateral as touchstone. If the Bank does not stand ready to lend freely on a good collateral, agents are forced to resort to fire sales of that collateral. Government securities therefore are sold on the market, rather than pledged at the central bank. The incidence of the crisis on 'safe' bond prices is thus a shadow measure of the extent to which lending-of-last-resort operations prevail. The stronger the price declines, the more likely it is that the Bank is not acting as a lender of last resort.

Figure 6 shows the behaviour the 'good security' par excellence, namely British consols, during the three crises under study. As before, we have associated the climax of the crisis with the suspension of the Act of Peel (relieving the Bank from its convertibility obligation), which

\footnotetext{
54 . Bagehot, Lombard Street, p. 202, quotes a very famous statement by Bank officials about their behavior during the 1825 crisis: 'We lent money by every possible means, and in modes which we had never adopted before; we took in stock on security, we purchased Exchequer Bills, we made advances on Exchequer Bills, we not only discounted outright, but we made advances on deposits of bills of Exchange to an immense amount - in short, by every possible means consistent with the safety of the Bank'.

55 . 'The Bank also advances on consols and India securities, though there was, in the crisis of 1866, believed to be for a moment a hesitation in so doing. But these are only a small part of the securities on which money in ordinary times can be readily obtained, and by which its repayment is fully secured. Railway debenture stock is as good a security as a commercial bill, and many people, of whom I own I am one, think it safer than India stock; on the whole, a great railway is, we think, less liable to unforeseen accidents than the strange Empire of India. But I doubt if the Bank of England in a panic would advance on railway debenture stock, at any rate no one has any authorized reason for saying that it would. And there are many other such securities'. Bagehot, Lombard Street, pp. 205-6.
} 
we take as benchmark, looking at the price of consols in the ten weeks before and after it. We see that the 1847 crisis seriously depreciated consols, but the two subsequent crises less so. The 1847 crisis saw a peak in depreciation of about $9 \%$ at the apex, while this was reduced to $4 \%$ during the 1857 crisis, and only to $2 \%$ during the 1866 crisis. We take this as a reflection of the fact that the central bank was lending freely on consols and that the market understood it: fire sales were avoided. This finding complements nicely the regression of credit rationing documented in the previous section. ${ }^{56}$

On this latter account, there is anecdotal but strong evidence that the crisis of 1847 again proved pivotal in shaping 'modern' views on crisis management as they would be later encapsulated in Bagehot's Lombard Street. One feature of this crisis that caught the attention of observers, was that price declines occurred across asset classes and infected top securities too. When in late September the Bank of England was reported to try and support the market by enlarging discounts of short bills, it was said to be curtailing its advances and thus limiting lending on consols and exchequer bills. The result may have been the strong decline observed in Figure 6. The Economist adhered to this interpretation, and reported negatively that the Bank was taking with one hand what it gave with the other. ${ }^{57}$ Historians of economic thought will pick the existence of a fair deal of pre-Bagehotian wisdom in this criticism. In any case, when Lombard Street was published, it really reflected much of the existing wisdom on crisis

\footnotetext{
${ }^{56}$. As for other features discussed in this article, qualitative sources provide anecdotal evidence backing our finding. For instance King, History, p. 243, emphasizes at the apex of the 1866 crisis, it was the Bank of England's announcement that 'loans on government securities would be available at $10 \%$ ' that restored liquidity in the market for consols.

57. The Economist, 2 October 1847: 'The Bank has experienced a great pressure, and has been obliged to decline paper to a large amount, as well as applications for advances on securities. After the weekly meeting on Thursday, a notice was issued, raising the rate of interest on advances again to 5,5\%; and this morning it was further intimated that no further advances whatever would be made upon consols, warrants, or Exchequer bills, the object being, it is said, to enable the Bank to make their advances more liberally on bills of exchange, to the aid of commerce. We fear, however, that in attempting to draw this distinction they have overlooked the fact, that advances made to brokers on stock are most generally on behalf of private bankers and bill brokers, who through their own connections can more effectually aid commerce than the Bank itself. It is impossible that any one can now fail to admit the error committed by the directors in the frequent changes which they have made within the last month in the terms for making advances'.
} 
management, as advocated by The Economist for a quarter of a century and as practiced by the Bank of England since the crisis of 1866. Bagehot would have probably agreed.

Figure 6 about here

Before we discuss Bagehot's last 'rule', a brief pause is in order. Economic historians have often described the period after 1873 as one of gradual adoption and triumph of Bagehot's principles at the Bank. ${ }^{58}$ The previous sections strongly suggest that 'triumph' must have been limited to the ideological field, not to the intellectual one. What occurred after 1873 was, at best, an official recognition of policies that the Bank of England already followed. Here we meet with and qualify the famous controversy sparked by publication of Lombard Street between Bagehot and Hankey. It is usually portrayed as a debate about the danger that Bagehot's rules would encourage moral hazard. That the rules described by Bagehot had been tacitly adhered to by British monetary authorities, as Bagehot actually claimed, implies that Hankey's rebuttal had mostly political and bureaucratic significance: the Bank of England did not want to lose any degree of freedom by committing itself to any pre-specified policy. ${ }^{59}$

This means that an interesting and heretofore never discussed issue is the extent to which the adoption of such new operating rules did indeed encourage moral hazard. To address it, we searched the Archive of the Bank of England for information on delinquency rates. The

\footnotetext{
58 . Fetter, Development, pp. 257-83.

59 . A parallel that comes to mind is the modern emphasis on what the European Central Bank calls 'constructive ambiguity' (see e.g. Presentation of the ECB's Annual Report 1998 to the European Parliament, Introductory statement delivered by Dr. Willem F. Duisenberg, President of the European Central Bank, Strasbourg, 26 October 1999) and the large economic literature on opacity (e.g. Svensson, 'Social value').
} 
information on this matter is organized in two registers that record the number of delinquent accounts and corresponding amounts on a yearly basis. ${ }^{60}$ The question we have in mind is whether there was an increase in delinquency following the generalization of modern lendingof-last-resort principles, as the moral hazard hypothesis would predict.

To deal with this question, it is important to get into some detail on the statistics of unpaid bills. In the Bank of England files, delinquency is organized on a per-discounter basis, not on a per-bill basis. This suggests the following operations. Within the mass of bills that the Bank of England discounted some were being returned unpaid, but the guarantees that had been taken prevented troubles from reaching the books of the Bank. The bill was thus paid, with the discounter making up for the loss. A tight correspondence between statistics for 'suspended discounters' and 'new [delinquent] accounts' suggests that if the discounter did not manage to make ends meet, he would loose access to the discount window. ${ }^{61}$ However, there could be cases where the discounter would not be able to provide the balance: this is when the material was entered in the books as a 'delinquent account', generally leading to the exclusion from the discounters' list. The Bank then opened a debit account for the delinquent individual, a debtor to the Bank. Revenues on this account (from the discounter, from the acceptor, or from endorsers and primary debtor if these were different individuals than the discounter) came as an offset: while a number of write-offs were made, the account started producing a revenue as some partial recovery occurred. Measuring the actual losses for such debit accounts would be a painful task. Random draws found that the amount lost were a trifle of initial sums. The eventual return occasionally outperformed early write-offs.

\footnotetext{
60. Bank of England Archive C 30/3 and C 34/4.

${ }^{61}$. One anecdote that underlines the importance of the fiduciary relationship between the Bank of England and its customers is provided by the experience of the Greek house of Vagliano, which attracted much contemporary interest. In 1889, it was discovered that a clerk working at Vagliano's had forged bills that he had then presented for discount at the Bank of England. The merchant bankers filed lawsuits against the Bank for having paid large sums over the counter to the clerk. They charged that the Bank ought to monitor the quality of bills (a quick inspection of the bill and account would have revealed the fraud), and lost. The House of Lords established that the discounter, not the Bank of England, was responsible for ensuring the quality of bills. Chatziioannou and Harlaftis, 'From the Levant', pp. 38-9.
} 
We conclude from previous discussion that the number of new delinquent accounts and the amounts inscribed to their debit are an indicator of the volume of problems that the Bank had to deal with. It is thus an indication of the quality of the safety nets that the Bank established for itself (and of course, of the overall quality of credit in the economy). We understand the concern of supporters of the moral hazard view to be that problems ought to have increased with the recognition of the role of the Bank of England as a lender of last resort.

The data we have collected enable us to reconstruct the number of delinquent accounts and amounts at risk of loss in London for the entire century between 1814 and 1914, as well as the total amounts at risk for both London and the provincial branches as a share of Bank of England total discounts for the period 1844-1914. Results are represented in Figures 7 and 8. There are many interesting insights that can be gleaned from these new charts. One is the occurrence of peaks in financial crises, with famous episodes being easily recognizable. We are also struck by the apparent virulence of the crisis of 1825 , which shows up with close to 100 problem accounts the next year. It is also interesting to see that crises tend to show up with a lag. The peak of problems was reached in 1849 for the crisis of 1847 , and in 1858 for the crisis of 1857 .

Another interesting message from the charts is about the geography of problems. As seen, branches' share in problems increased over time, and delinquency remained marginally more substantial there. Branches were a greater source of concern until the end of the period. This may have been a reflection of the fact that, as some earlier writers have suggested, branches were softer than London during the 1850 s and possibly beyond. ${ }^{62}$

But the overarching message is that the amounts at risk became really negligible by 1873 . There was a general decline in the total number of problems and their extent. This is quite

\footnotetext{
${ }^{62}$. Ziegler, Central banking; King, History, pp. 188-189.
} 
discernible for London data, with problems essentially disappearing by the time Bagehot wrote Lombard Street, but the trend is evident for the Bank of England at large.

There can be only two possible interpretations. The first is that the world became a safer place after 1873, so that there were just less problems around. This in itself would run against the moral hazard story, because it suggests that the development of lending-of-last-resort operations was followed by an improvement rather than a deterioration of credit quality. A more credible alternative, however, is that as the Bank of England extended its crisis management operations, it also became increasingly more demanding regarding the requirements it put on agents discounting with it. The suggested interpretation is that its net exposure to market risk went down, because discounters were called on their capital to make up for any loss on discounted instruments, thus eliminating moral hazard. We conclude that free lending against good collateral has nothing to do with moral hazard and an expectation to be 'bailed out'. The historical fact is that the early development of lending of last resort had, as companion feature, a greater emphasis on quality.

Figures 7 and 8 about here

It is interesting to compare the record of the Bank of England with that of the Bank of France. Strict matching of data is difficult, however, owing to the way the two central banks organized their statistics on unpaid bills. While we saw that the Bank of England operated a per-discounter scheme, the Bank of France collected information at the individual bill level, counting the totals that were returned unpaid. But this very heterogeneity in record keeping may have reflected differences in operation, and in particular the fact that the Bank of England strongly relied on intermediaries while the Bank of France retained a greater role in 
origination of commercial paper, purchasing paper of which it was a discounter and thus in effect taking more exposure.

Figure 9 compares the evolution of amounts at risk for both central banks. The pattern observed for the Bank of England does obtain for the Bank of France as well, with the amount of unpaid bills as a percentage of total discounts declining steadily over time. ${ }^{63}$ Along with the material already reported - indicating that the Bank of France was moving from a policy of credit rationing to a policy of genuine support of the market in case of crises - this evidence suggests that, beyond differences between the two institutions, more careful screening of the paper taken was there too a companion feature of the emergence of modern lending of last resort.

Finally, this section would not be complete if we did not emphasize the substantially higher share of problem bills in the case of France. The Bank of England operated in an almost perfectly risk-free market, whereby losses were entirely transferred to market participants. In the French system, by contrast, risks (however small) were taken and had to be managed on a case-by-case basis. ${ }^{64}$ To what extent the English situation was made possible by some specific features of the London market for acceptances - and to what extent central bank operations reinforced these features - is an important subject which future research will have to address.

Figure 9 about here

\footnotetext{
63. This decline is obtained in a context of rising aggregate default in France, as measured by the bankruptcy rate of firms (the number of firms going bankrupt, normalized by the numbers of existing firms). This rate increased steadily from about $0.15 \%$ in the 1820 s to $0.6 \%$ in the 1890 s (Bignon, 'Financial crises'). This suggested that the central bank was able to reduce its exposure when overall risks were rising, and reinforces our conclusions. Baker and Collins, Commercial banks, p. 247, report 0.19\% average losses for a sample of 3,010 industrial loans covering the period 1875-1914.

${ }^{64}$. On the Bank of France as an originator of bills, see Nishimura, 'The French provincial banks', pp. 543 and 547.
} 
This last of the three Bagehotian rules is the trickiest, not least because Bagehot never used the word 'penalty'. Instead he spoke about 'high' or sometimes 'very high' rates. This point has already made before, ${ }^{65}$ but the reference to 'penalty' rates is an enduring one. Of course, the notion that rates rise during a crisis is consistent with different views. First, during a panic, the number of suppliers of short-term credit declines while demand increases. This situation naturally brings the market inside the central bank. The recommendation to use high rates could thus be taken as an encouragement not to 'sterilize' the effect of the crisis and could be motivated by extraneous objectives. An alternative (not exclusive) interpretation would emphasize the role of higher rates in sorting debtors. Principal-agent theory suggests that with imperfect information, reward is proportionate to effort. The clear announcement that, in the event of a crisis, the houses seeking support will face high funding cost may have a disciplinary effect.

In Lombard Street, the 'high rates' are motivated in a variety of ways. ${ }^{66}$ The first is reference to Britain's exchange rate regime - the gold standard. It is explicit and perfectly transparent in several parts of Lombard Street. In one often quoted part, Bagehot writes about the need for 'very large loans at very high rates [being] the best remedy for the worst malady of the money market when a foreign drain is added to a domestic drain' ${ }^{67}$ A crisis-stricken gold-standard country is presumably confronted with a gold outflow. The free supply of liquidity by the central bank would create a conflict with the exchange rate regime. One would therefore need to combine generous credit to defend the banking system and high rates

\footnotetext{
65. See e.g. Goodhart, 'Myths', p. 341.

${ }^{66}$. A third one, which is discussed in various parts, has to do with the need that the bank rate be located above the market rate, as already indicated, and in this sense is 'higher'. We shall not devote time to this matter.

67. Bagehot, Lombard Street, pp. 56-7.
} 
to defend the parity. ${ }^{68}$ If this is the justification for the 'high interest rates', then the third rule is not part of the standard recipe for lending of last resort. It is part of a different toolbox, intended to deal with a current account crisis.

But Lombard Street contains a second interpretation. ${ }^{69}$ It is better to quote Bagehot entirely, without any editing or additions:

'First. That these loans should only be made at a very high interest rate. This will operate as a heavy fine on unreasonable timidity, and will prevent the greatest number of applications by persons who do not require it. The rate should be raised early in the panic, so that the fine may be paid early; that no one may borrow out of idle precaution without paying well for it; that the banking reserve may be protected as far as possible'.

As seen, the notion that the banking reserve should be protected is mentioned again, but it comes along with an argument about taxing timidity that relies explicitly on a hypothesized asymmetry of information. However, the asymmetry of information Bagehot has in mind is not about the difficulty of sorting debtors. It is about preventing that the not needy gets the fund. The resulting 'fine' (a concept that gets as close to penalty as Bagehot ever was) is imposed not on the weak bank but on the defiant lender, and is therefore tantamount to a tax on those responsible for the liquidity squeeze. The 'punishing' ingredient involved, therefore, has to do with correcting the behaviour of those who have available resources but withdraw them from the market. The Bank is substituting for a supply that ought not to have disappeared, and the high rates of interest are an indication that the arrangement cannot last. In other words, by raising the opportunity cost of not lending, the central bank encourages a

\footnotetext{
${ }^{68}$. Several digressions by Bagehot dwell on this mechanism. In one place, he seems to suggest that the raising of the interest rates might be avoided, if the external drain were not taking place (Bagehot, Lombard Street, pp. 4757). The already quoted Bank of England Memorandum suggested that credit rationing was a policy whose 'course appears to have been taken as one of the measures for securing the convertibility of the Bank Notes'. This interpretation is consistent with a number of earlier papers, including: Humphrey, 'The classical concept'; Humphrey and Keleher, 'The lender'; Martin, 'Reconciling Bagehot'.

${ }^{69}$. Bagehot, Lombard Street, p. 197. It is not really echoed in other parts of the book, nor is it discussed again later.
} 
revival of the inter-bank market and signals its unwillingness to be the market maker of last resort. $^{70}$

Bagehot's argument may be better understood in the light of some technical background elements. Bankers' balances at the Bank of England substituted against deposits at the Clearing House and thus provided a safe alternative to inter-bank lending and clearing. Banks could seek cash by parking good securities with the Bank of England or sell to the Bank any surplus bills they would have. This flight to safety would manifest itself through a liquidity squeeze. The insurance came at a price controlled by the Bank: since the Bank of England did not pay interest on its deposits, the opportunity cost of withdrawing balances from the market would essentially be the bank rate. In the end, the high interest rates - which Bagehot insisted had to be used very early on - could provide monetary authorities with a powerful tool to prevent the complete collapse of inter-bank lending.

This conclusion and interpretation of Bagehot's third rule calls for a comparison with modern issues: the anachronistic use of history can be inspiring. In the recent crisis, some observers have expressed concerns that low interest rates set by the Bank of England, combined with its new policy of paying interest on banks' deposits, ${ }^{71}$ have done little to resuscitate the moribund money market. Our analysis suggests that if modern authorities had wanted to follow Bagehot's advice, they should have lent on good collateral only at penalty rates, instead of lending at very low rates on poor-quality financial products. Would that have worked? In the unlikely case economists ended up reading these pages, they should let us know.

\footnotetext{
${ }_{71}^{70}$. On this point, Bagehot and Hankey were in full agreement: see Hankey, The principles, pp. 27-29.

71 . Tim Congdon and Brandon Davies argued, in an article entitled 'A Simple Plan to Unclog the Interbank Market' published in the Financial Times (22 October 2008), that 'another contrast with the historical norm is that since 2006, UK banks have received interest on their balances at the central bank. For more than 300 years from its founding in 1694 the Bank had resisted paying interest on such balances [...] for each bank it is indeed true that the payment of interest on cash balances is good for profit. But a case can be made that the earning of these profits, which are in any case trivial relative to total profits, has undermined liquidity in the interbank market. The point is that if a particular bank's treasury executives know that interest can be earned in a balance at the central bank they are under less pressure to lend out that cash to other banks'.
} 


\section{VII}

This article has reviewed the early formation of lending-of-last-resort operations at a time when modern ideas got shaped. As we indicated in the introduction, the matter may have interest for historians of economic thought, economic historians, macroeconomists, theorists, and policymakers.

For historians of thought, our article suggests that a lot of the Bagehotian wisdom articulated in Lombard Street was really a reflection of ideas and thoughts that had matured in the previous quarter of a century, in large part in response to the crises of 1847 and before during which the Bank of England had relied on credit rationing.

For economic historians, the analysis above shows that during the 1850s and 1860s the Bank of England (just like some other prominent central banks, such as the Bank of France) was on a learning curve and began to implement lending of last resort along lines that anticipated on Bagehot's teachings. That they did it in such a perfect tune does cast doubts on simple-minded attempts at relating the transformation in policy making to domestic factors, institutions, and exchange rate regimes. ${ }^{72}$ We want to flag this for future research.

For macroeconomists, our study provides evidence of the strong effect that the development of lending-of-last-resort operations had on the stability of the price of 'good collaterals', as often hypothesized but not so often actually shown. While government securities used to be the object of fire sales and their price thus highly volatile, they became

\footnotetext{
${ }^{72}$ On the other hand, relevance should not be dismissed off hand either: there may have been something 'natural' in the development of lending of last resort in a system where the central bank is private since, as emphasized by Flandreau, 'Pillars of globalization', lending of last resort is really profit making.
} 
steady and a source of resilience in the financial system owing to the emergence of modern lending-of-last-resort operations.

For policymakers, our article presents a challenge. We found that one possible rationalization of Bagehot's emphasis on high rates (consistent with both his writings and the empirical evidence of the time) is that the central bank ought to restore the normal functioning of the market by punishing agents who seek safety in holding their reserves at the central bank rather than lending them to the market. The intuition is that there must exist a threshold discount rate at which banks are led to resume lending. And since at the same time the Bank keeps lending on 'good collateral', the effect of this policy on the cost of credit, better captured by the yields of long-term bonds, is moderate. We suggested that if this is true, then central banks have been erring on the wrong side of Bagehot's teaching during the recent subprime crisis.

For theoreticians, we finally uncovered a puzzle. Far from encouraging moral hazard, we saw that the development of lending-of-last-resort operations was accompanied by a quasicomplete disappearance of delinquent accounts at the Bank of England. We suggested that this may be rationalized in reference to greater guarantees that central banks took at the same time they started adopting more generous lending patterns. This important finding - it means that in the real world, lending of last resort and moral hazard are different subject matters implies that something is missing in the modern theoretical literature. 


\section{References}

Acharya, V. V., Gromb, D., and Yorulmazer, T., 'Imperfect competition in the interbank market for liquidity as a rationale for central banking', mimeo (2008).

Allen, F., and Gale, D., 'Optimal financial crises', Journal of Finance, 53 (1998), pp. 1245-84.

Andolfatto, D., Nosal, E., and Wallace, N., , 'The role of independence in the DiamondDybvig Green-Lin model', Journal of Economic Theory, 137 (2007), pp. 709-15.

Antinolfi, G., Huybens, E., and Keister, T., 'Monetary stability and liquidity crises: the role of the lender of last resort', Journal of Economic Theory, 99 (2001), pp. 187-219.

Bagehot, W., Lombard Street: a description of the money market (London, $5^{\text {th }}$ edn. 1873).

Baker, M., and Collins, M., Commercial banks and industrial finance in England and Wales, 1860-1913 (Oxford, 2003).

Bignon, V., 'Financial crises, business cycles, and bankruptcies in the very long run: France during the $19^{\text {th }}$ century', mimeo (2011).

Bindseil, U., Monetary policy implementation: theory, past, present (Oxford, 2004).

Bordo, M. D., 'The lender of last resort: alternative views and historical experience', Federal Reserve Bank of Richmond Economic Review, Jan./Feb. 1990, pp. 18-29.

Champ, B., Smith, B. D., and Williamson, S. D., 'Currency elasticity and banking panics: theory and evidence', The Canadian Journal of Economics 29 (1996), pp. 828-64.

Chari, V.V., and Jagannathan, R., 'Banking panics, information, and rational expectations equilibrium', Journal of Finance 43 (1988), pp. 749-63.

Chatziioannou, M.-C., and Harlaftis, G., 'From the Levant to the City of London: mercantile credit in the Greek international commercial networks of the $18^{\text {th }}$ and $19^{\text {th }}$ centuries', in Cottrell, P. L., Lange, E., and Olsson, U. (eds.), Centres and peripheries in banking: the historical development of financial markets (Aldershot, 2007), pp. 13-40.

Clapham, J. H., The Bank of England: a history, 2 vols. (Cambridge, 1944).

Collins, M., 'The Langton Papers: banking and Bank of England policy in the 1830s', Economica, New Series, 39 (1972), pp. 47-59.

Collins, M., 'The Bank of England as lender of last resort, 1857-1878', Economic History Review, 45 (1992), pp. 145-53.

Cooper, R., and Ross, T. W., 'Bank runs: liquidity costs and investment distortions', Journal of Monetary Economics, 41 (1998), pp. 27-38.

Diamond, D. W., and Dybvig, P. H., 'Bank runs, deposit insurance, and liquidity', Journal of Political Economy, 91 (1983), pp. 401-419.

Fetter, F. W., Development of British monetary orthodoxy, 1797-1875 (Oxford, 1965).

Flandreau, M., The glitter of gold: France, bimetallism and the emergence of the international gold standard, 1848-1873 (Oxford, 2004).

Flandreau, M., 'Pillars of globalization: a history of monetary policy targets, 1797-1997', in Beyer, A., and Reichlin, L. (eds.), The role of money: money and monetary policy in the $21^{\text {st }}$ century (Frankfurt-am-Main, 2008), pp. 208-43. 
Flandreau, M., Galimard, C., Jobst, C., and Nogués-Marco, P., 'The bell jar: commercial interest rates between two revolutions, 1688-1789', in Atack, J., and Neal, L. (eds.), The origins and development of financial markets and institutions (Cambridge, 2008), pp. 161208.

Flandreau, M., and Ugolini, S., 'Where it all began: lending of last resort and the making of sterling as the leading international currency in the 1860s', mimeo (2010).

Freeman, S., 'The payments system, liquidity, and rediscounting', American Economic Review 86 (1996), pp. 1126-38.

Freixas, X., Parigi, B. M., and Rochet, J.-C., 'The lender of last resort: a twenty-first century approach', Journal of the European Economic Association, 2 (2004), pp. 1085-115.

Freixas, X., Giannini, C., Hoggarth, G., and Soussa, F., 'Lender of last resort: a review of literature', Financial Stability Review, November 1999, pp. 151-67.

Friedman, M., and Schwartz, A. J., A monetary history of the United States, 1867-1960 (Princeton, 1963).

Gilbart, J. W., A practical treatise on banking (London, $6^{\text {th }}$ edn. 1856).

Goodfriend, M., and King, R. G., 'Financial deregulation, monetary policy, and central banking”, in Haraf, W. S., and Kushmeider, R. M. (eds.), Restructuring banking and financial services in America (Washington, 1988), pp. 216-53.

Goodhart, C. A. E., 'Why do banks need a central bank?', Oxford Economic Review, 39 (1987), pp. 75-89.

Goodhart, C. A. E., The evolution of central banks (Cambridge (Mass.), 1988).

Goodhart, C. A. E., 'Myths about the lender of last resort', International Finance, 2 (1999), pp. 339-60.

Gorton, G. B., 'Banking panics and business cycles', Oxford Economic Papers, 40 (1988), pp. 751-81.

Gorton, G. B., 'The panic of 2007', in Maintaining stability in a changing financial system: proceedings of the 2008 Jackson Hole conference (Kansas City, 2008), pp. 131-262.

Gorton, G. B., and Huang, L., 'Banking panics and the origin of central banking', in Altig, D. E., and Smith, B. D. (eds.), Evolution and Procedures of Central Banking (Cambridge, 2003), pp. 181-219.

Gorton, G. B., and Huang, L., 'Bank panics and the endogeneity of central banking', Journal of Monetary Economics, 53 (2006), pp. 1613-29.

Green, E. J., and Lin, P., 'Implementing efficient allocations in a model of financial intermediation', Journal of Economic Theory, 109 (2003), pp. 1-23.

Green, J. H., 'Repurchase agreements: advantages and implementation issues', IMF Monetary and Exchange Affairs Department operational paper 97/03 (1997).

Hankey, T., The principles of banking, its utility and economy, with remarks on the working and management of the Bank of England (London, 1867).

Haupt, O., Arbitrages et parités (Paris, $8^{\text {th }}$ edn. 1894).

Hughes, J. R. T., Fluctuations in trade, industry, and finance: a study of British economic development, 1850-1860 (Oxford, 1960). 
Humphrey, T. M., 'The classical concept of the lender of last resort', Federal Reserve Bank of Richmond Economic Review, Jan./Feb. 1975, pp. 2-9.

Humphrey, T. M., and Keleher, R. E., 'The lender of last resort: a historical perspective', Cato Journal, 4 (1984), pp. 275-321.

Jacklin, C. J., and Bhattacharya, S., 'Distinguishing panics and information-based bank runs: welfare and policy implications', Journal of Political Economy, 96 (1988), pp. 568-92.

Jobst, C., 'Gouverner une banque centrale décentralisée: l'exemple austro-hongrois, 18471914', mimeo (2007).

Kaufman, G. G., 'Lender of last resort: a contemporary perspective', Journal of Financial Services Research, 5 (1991), pp. 95-110.

King, W. T. C., History of the London discount market (London, 1936).

Martin, A., 'Liquidity provision vs. deposit insurance: preventing bank panics without moral hazard', Economic Theory, 28 (2006), pp. 197-211.

Martin, A., 'Reconciling Bagehot and the Fed's response to September 11', Journal of Money, Credit and Banking, 41 (2009), pp. 397-415.

Matthews, R. C. O., A study in trade cycle history, 1833-42 (Cambridge, 1954).

Mints, L. W., A history of banking theory: in Great Britain and the United States (Chicago, 1945).

Morgan, E. V., , 'Railway investment, Bank of England policy and interest rates, 18441848', Economic History 4 (1940), pp. 329-40.

Morier Evans, D., The commercial crisis, 1847-1848: being facts and figures (London, 1849).

Nishimura, S., 'The French provincial banks, the Banque de France, and bill finance, 18901913', Economic History Review, 48 (1995), pp. 536-54.

Plessis, A., Histoires de la Banque de France (Paris, 1998).

Postlewaite, A., and Vives, X., 'Bank runs as an equilibrium phenomenon', Journal of Political Economy, 95 (1987), pp. 485-91.

Repullo, R., 'Who should act as a lender of last resort? An incomplete contracts model', Journal of Money, Credit and Banking, 32 (2000), pp. 580-605.

Rochet, J.-C., and Vives, X., 'Coordination failures and the lender of last resort: was Bagehot right after all?', Journal of the European Economic Association, 2 (2004), pp. 111647.

Roulleau, G., Les règlements par effets de commerce en France et à l'étranger (Paris, 1914).

Sayers, R. S., Bank of England operations, 1890-1914 (London, 1936).

Schwartz, A. J., 'The misuse of the Fed's discount window', Federal Reserve Bank of St. Louis Review, Sep./Oct. 1992, pp. 58-69.

Secret Committee on the Causes of the recent Commercial Distress and how far it has been affected by the Laws for regulating the Issue of Bank Notes Payable on Demand, 1848, P.P. 1847-8 (395). Part I. 1; 1847-8 (584) VIII. Part I. 505; and 1847-8 (395-584) VIII Part II. I and 379 . 
Secret Committee of the House of Lords on the Causes of the Distress which has for some time prevailed among the Commercial Classes and how far it has been affected by the Laws for regulating the Issue of the Bank of England Notes payable on Demand, 1848, P.P. 1847-8 (565) VIII. Part I and 537.

Select Committee on the Operation of the Bank Act of 1844 (7 and 8 Vict., c. 32) and the Bank Acts for Ireland and Scotland (8 and 9 Vict., c. 37 and 38), 1857, P.P. 1857 (220, Sess. 2)X. Part I. 1, and Part II. 1.

Select Committee on the Operation of the Bank Act of 1844 (7 and 8 Vict., c. 32) and the Bank Acts for Ireland and Scotland (8 and 9 Vict., c. 37 and 38), and the causes of the recent Commercial Distress and how far it has been affected by the Laws for Regulating the Issue of Bank Notes payable on Demand, 1858, P.P. 1857-8 (381) IX. 1.

Seyd, E., Bullion and foreign exchanges, theoretically and practically considered (London, 1868).

Sheng, A., 'Role of the central bank in banking crisis: an overview', in Downes, P., and Vaez-Zadeh, R. (eds.), The evolving role of central banks (Washington, 1991), pp. 193-217.

Sleet, C., and Smith, B. D., 'Deposit insurance and lender-of-last-resort functions', Journal of Money, Credit and Banking, 32 (2000), pp. 518-75.

Summers, B. J., 'Clearing and payment systems: the central bank's role', in Downes, P., and Vaez-Zadeh, R. (eds.), The evolving role of central banks (Washington, 1991), pp. 30-45.

Svensson, L. E. O., 'Social value of public information: comment: Morris and Shin (2002) is actually pro-transparency, not con', American Economic Review, 96 (2006), pp. 448-52.

Ugolini, S., 'The international monetary system, 1844-1870: arbitrage, efficiency, liquidity', mimeo (2010).

Vitu, A., Guide financier: répertoire général des valeurs financières et industrielles cotées sur les bourses françaises et sur les principaux marchés de l'Europe, de l'Amérique et des Indes (Paris, 1864).

Wallace, N., 'Another attempt to explain an illiquid banking system: the Diamond and Dybvig model with sequential service taken seriously', Federal Reserve Bank of Minneapolis Quarterly Review, 12 (1988), pp. 3-16.

Williamson, S. D., 'Discount window lending and deposit insurance', Review of Economic Dynamics, 1 (1998), pp. 246-75.

Williamson, S. D., 'Limited participation, private money, and credit in a spatial model of money', Economic Theory, 24 (2004), pp. 857-75.

Withers, H., The meaning of money (London, 1909).

Wood, E., English theories of central banking control, 1819-1858, with some account of contemporary procedure (Cambridge (Mass.), 1939).

Ziegler, D., Central banking, peripheral industry: the Bank of England in the provinces, 1826-1913 (Leicester, 1990). 
Table 1. Interest rates and maximum maturities at the Bank of France, 1800-1863. 8. Tariations de lescompito.

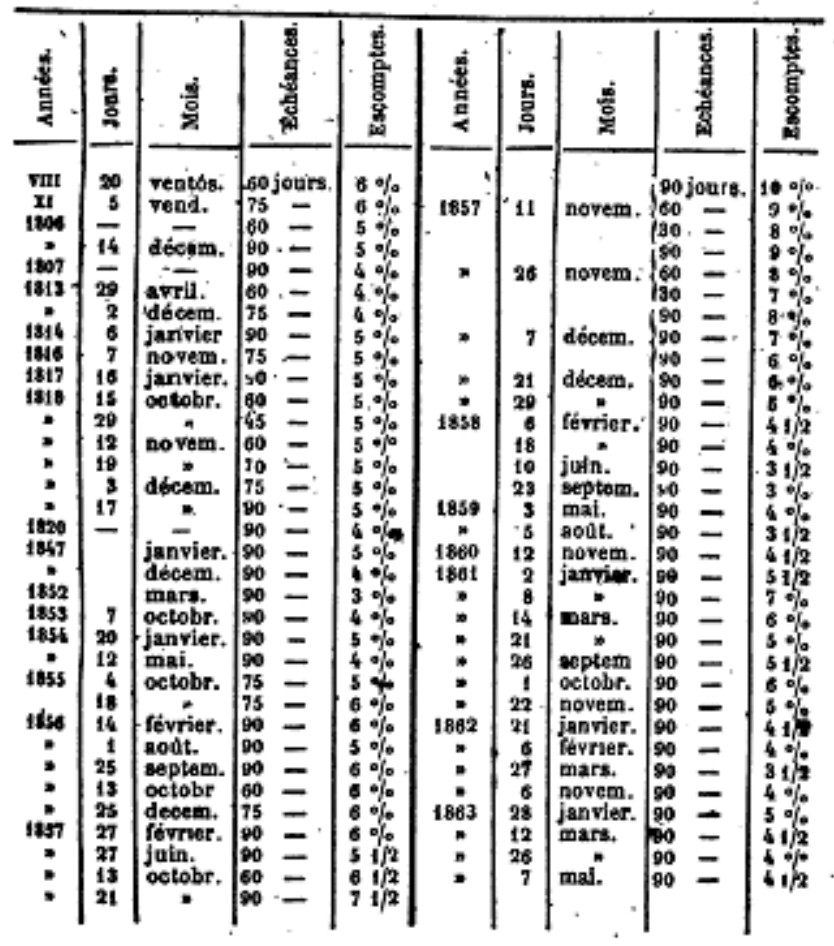

Source: Vitu, Guide financier, p. 305. 
Figure 1. Number of discounters at the Bank of England.

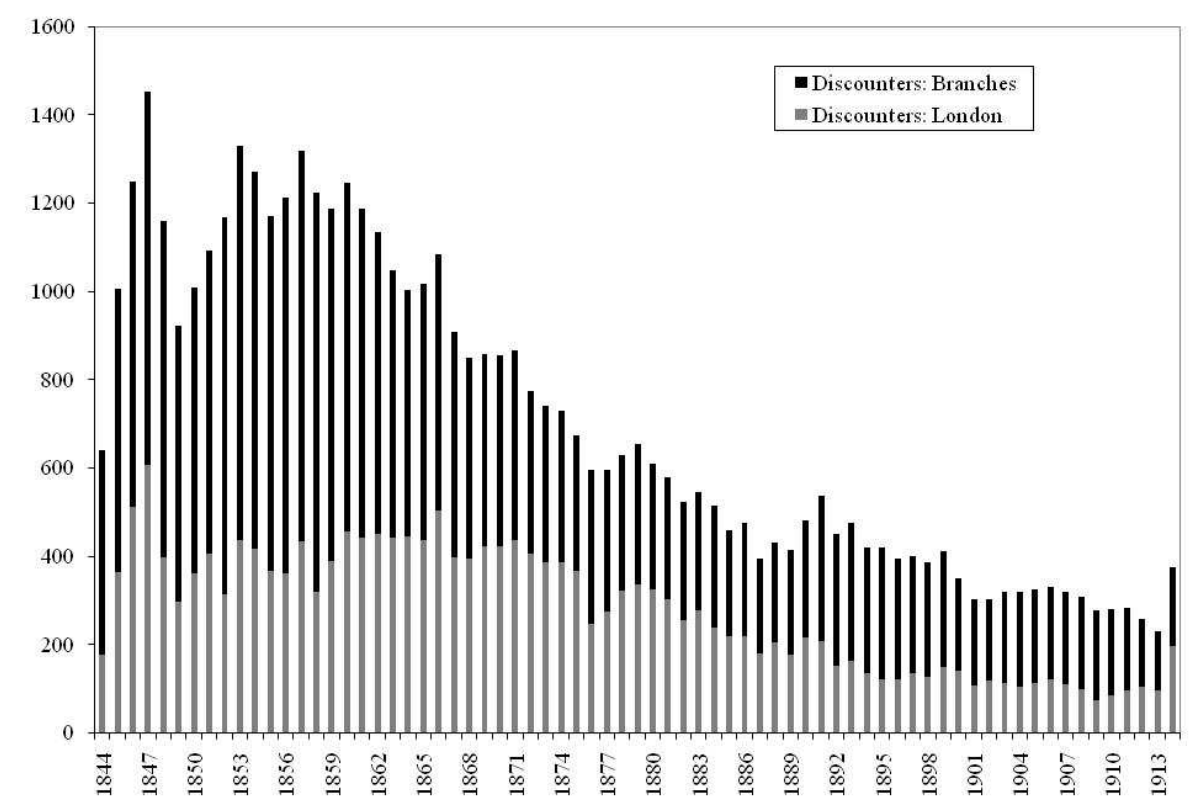

Source: Bank of England Archive, C30/3. 
Figure 2 a. Credit rationing and the crisis of 1847.

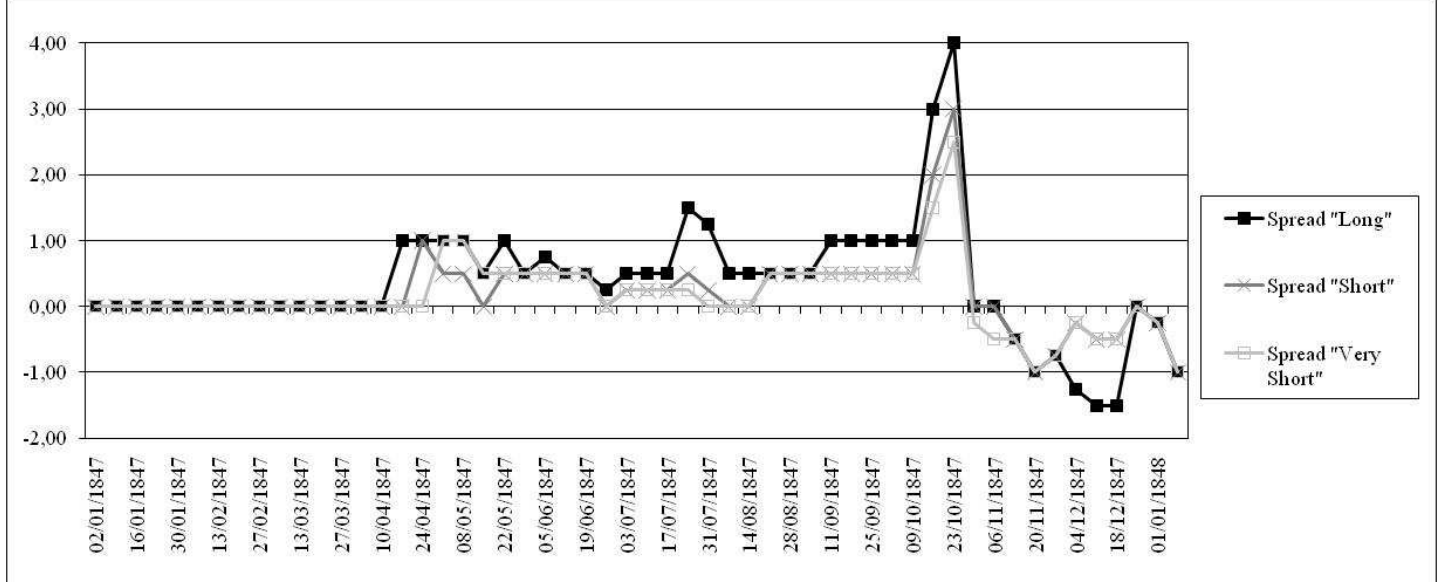

Source: Authors, from The Economist. 
Figure 2 b. Credit rationing and the crisis of 1857.

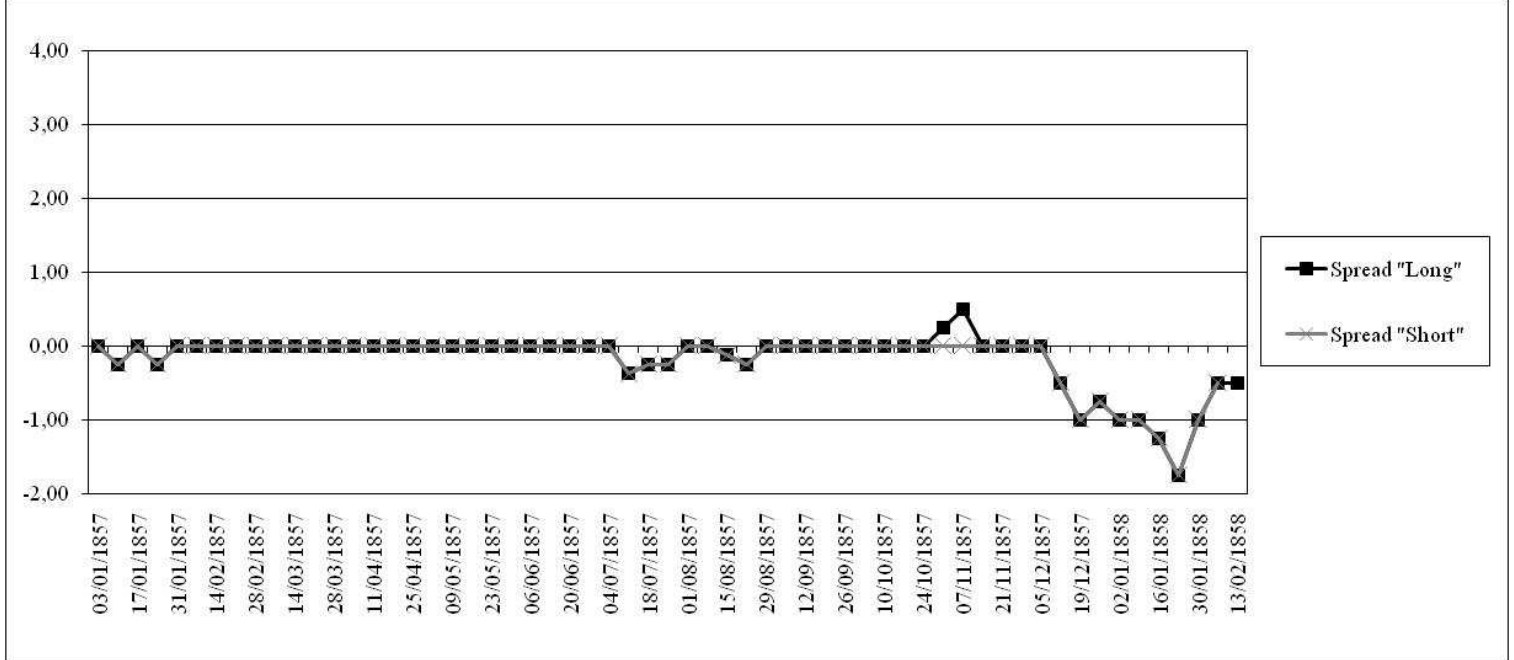

Source: Authors, from The Economist. 
Figure 2 c. Credit rationing and the crisis of 1866.

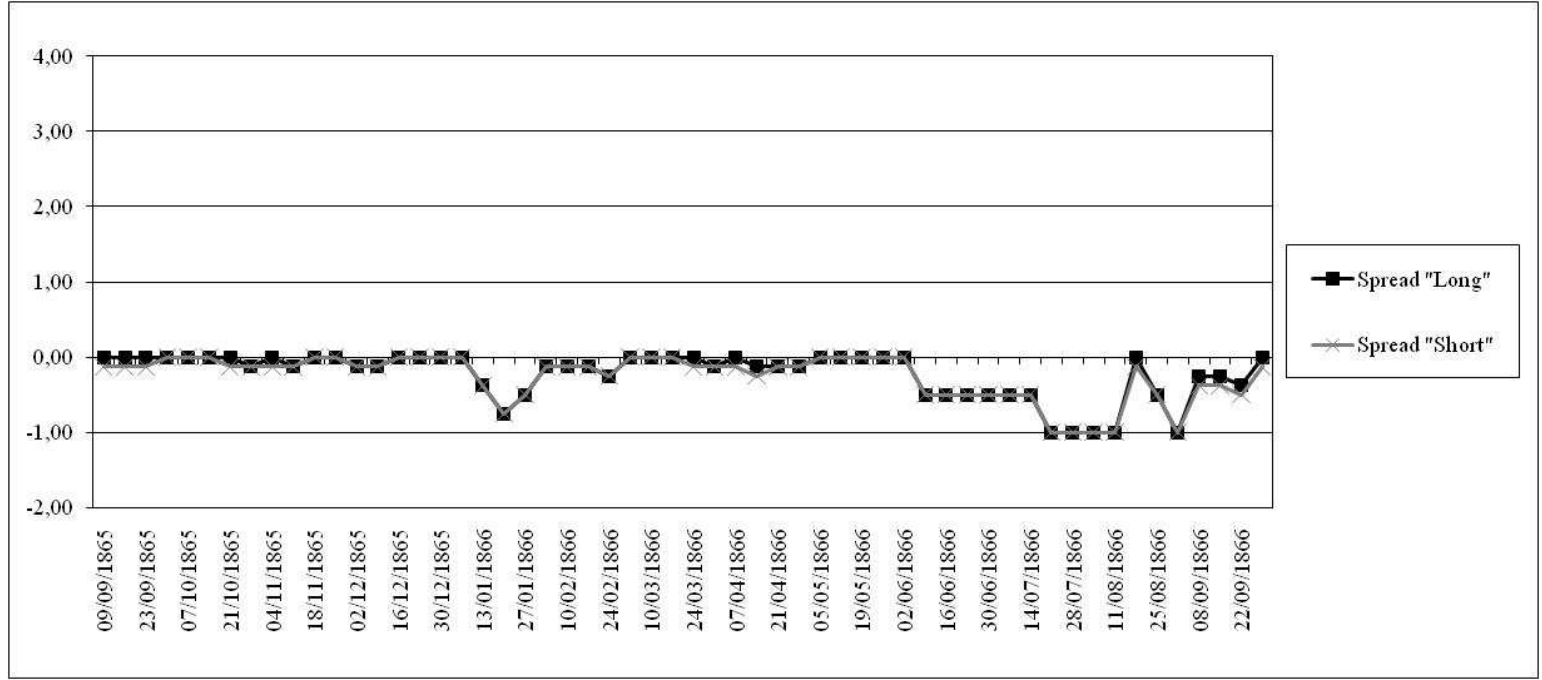

Source: Authors, from The Economist. 
Figure 3 a. Monthly totals for bills discounted and rejected: 1847 .

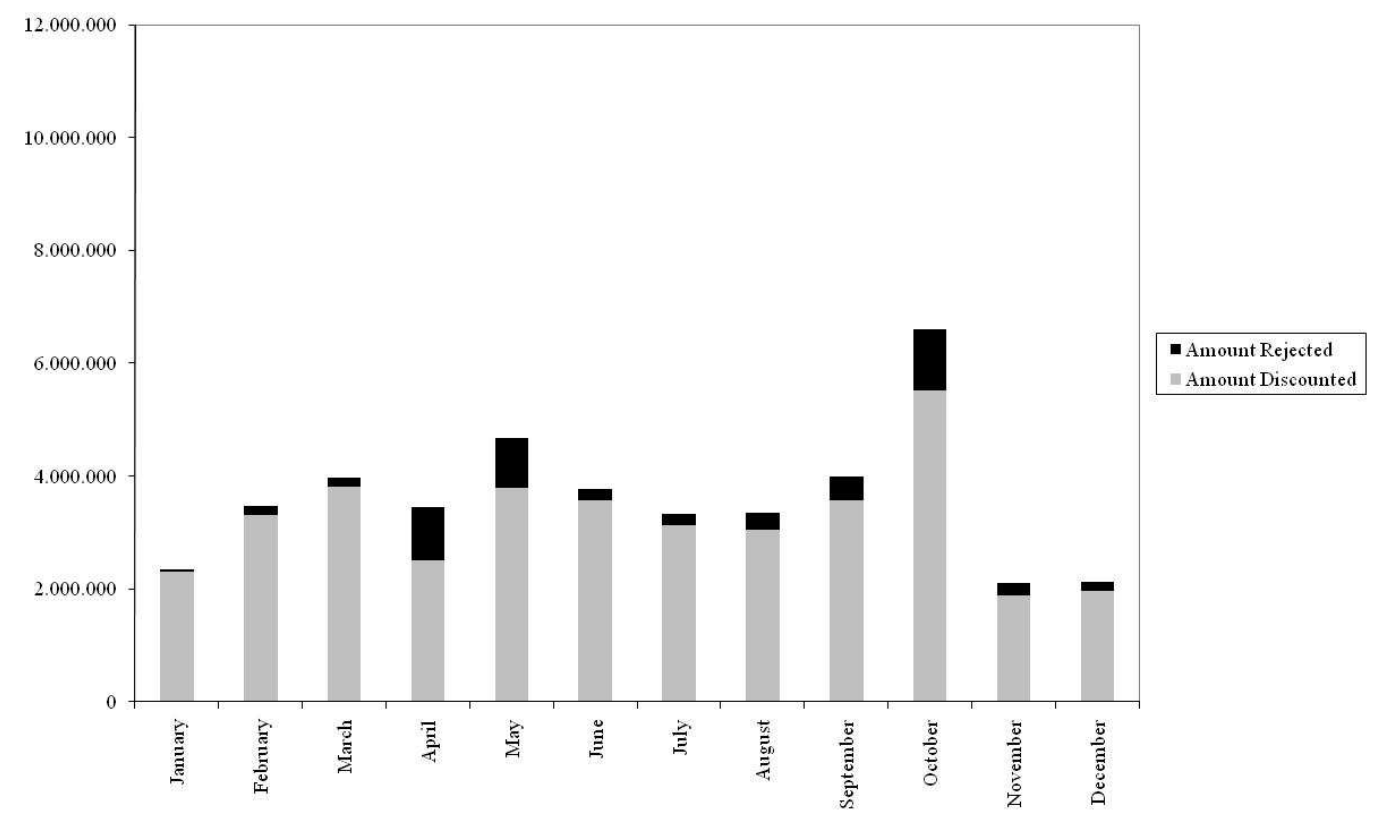

Source: Authors' computations, Bank of England Archive, C28/7. 
Figure 3 b. Monthly totals for bills discounted and rejected: 1857 .

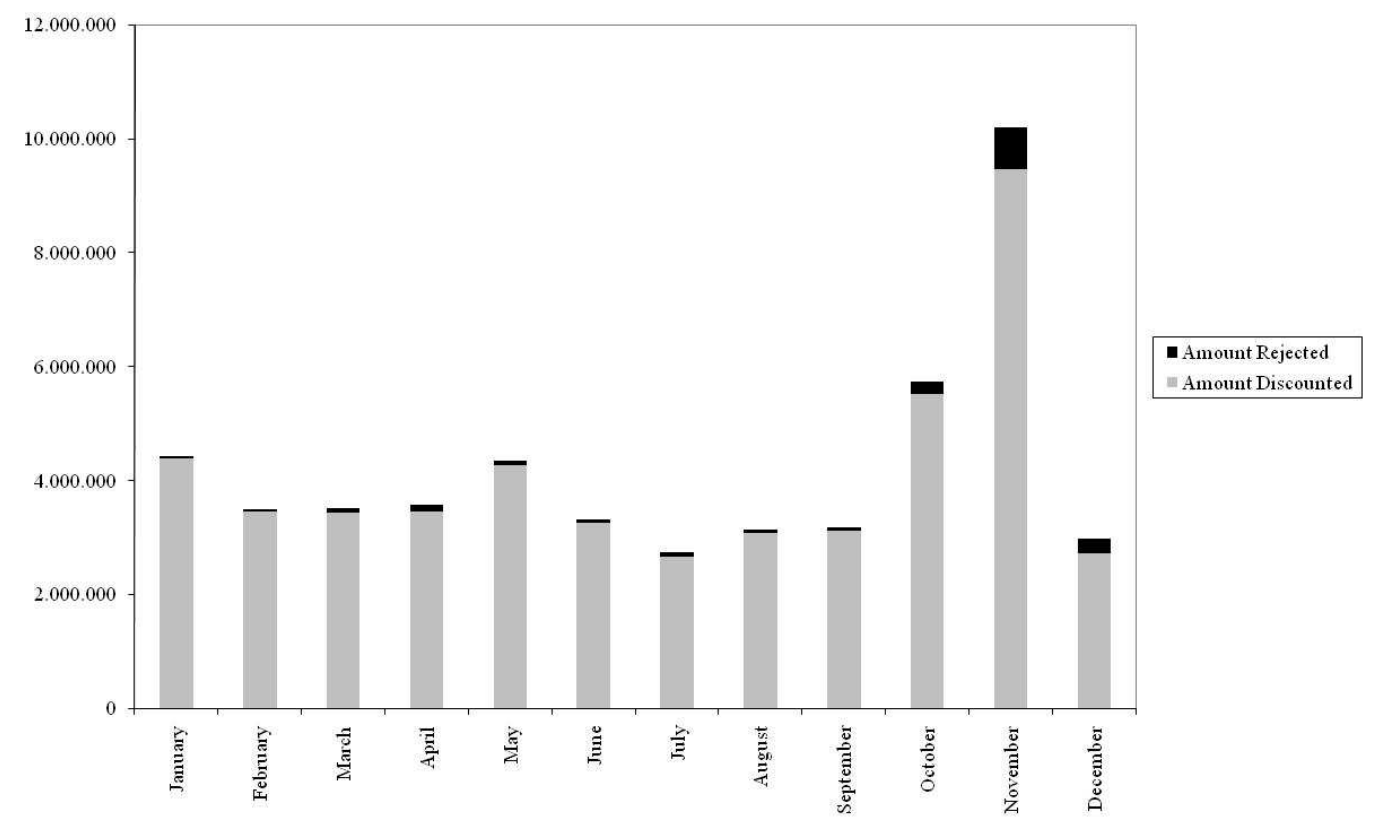

Source: Authors' computations, Bank of England Archive, C28/17. 
Figure 3 c. Monthly totals for bills discounted and rejected: 1866.

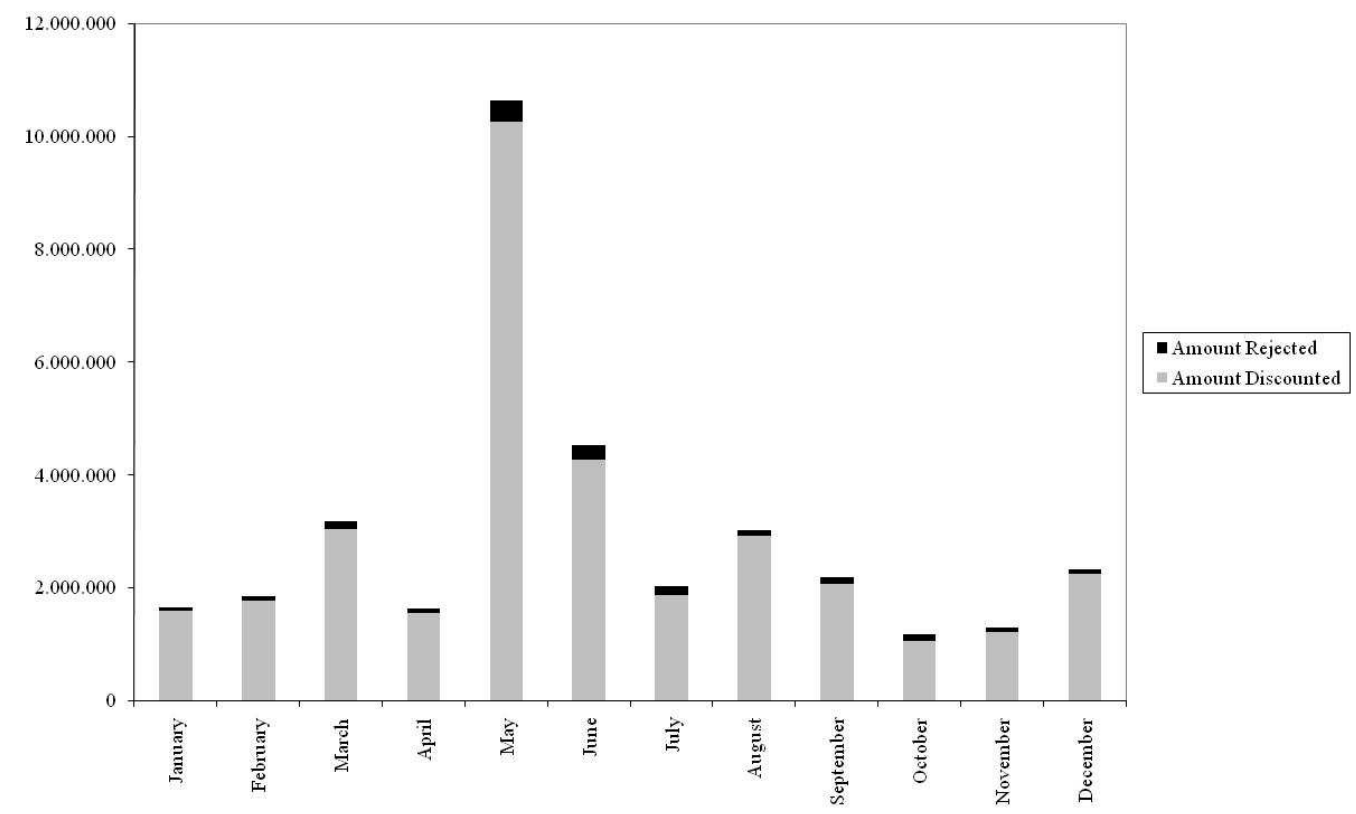

Source: Authors' computations, Bank of England Archive, C28/26. 
Figure 4. Market and bank rates in Paris, 1820-1882.

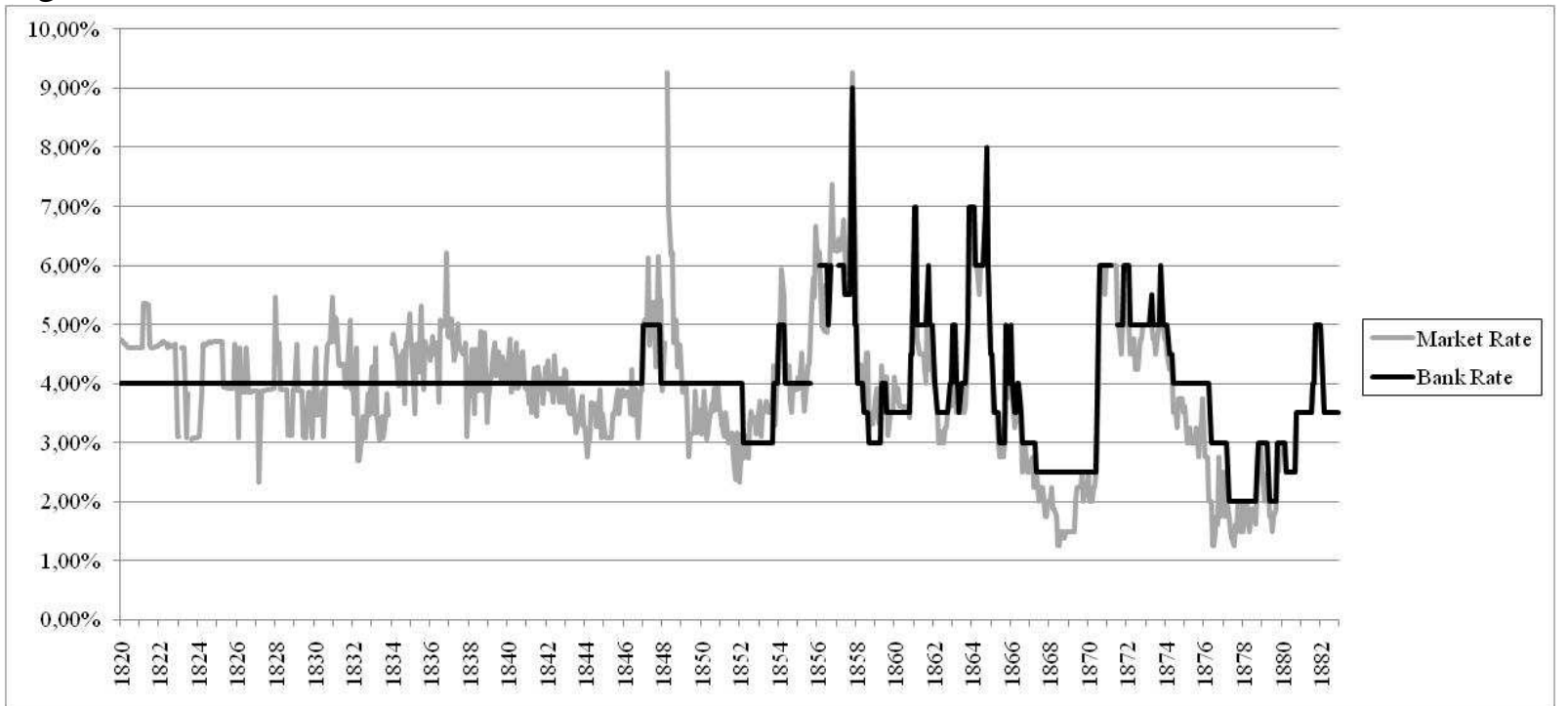

Source: Authors' computations on a variety of sources. 
Figure 5. Bills discounted and advances for short periods.

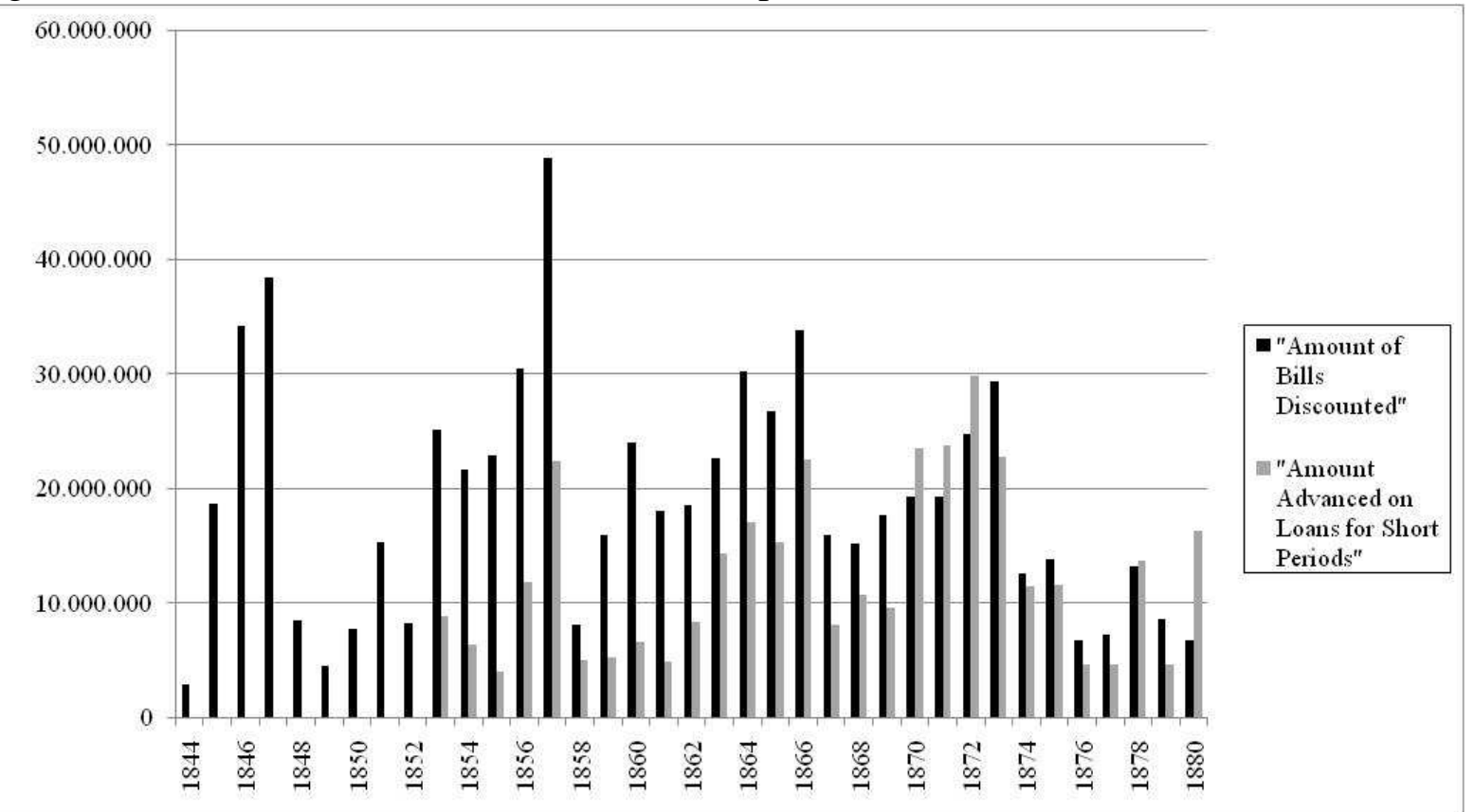

Source: Authors', from Bank of England Archive C30/3, 'Amounts advanced for short periods' (pre-1853 not available). 
Figure 6. Consol prices during three crises.

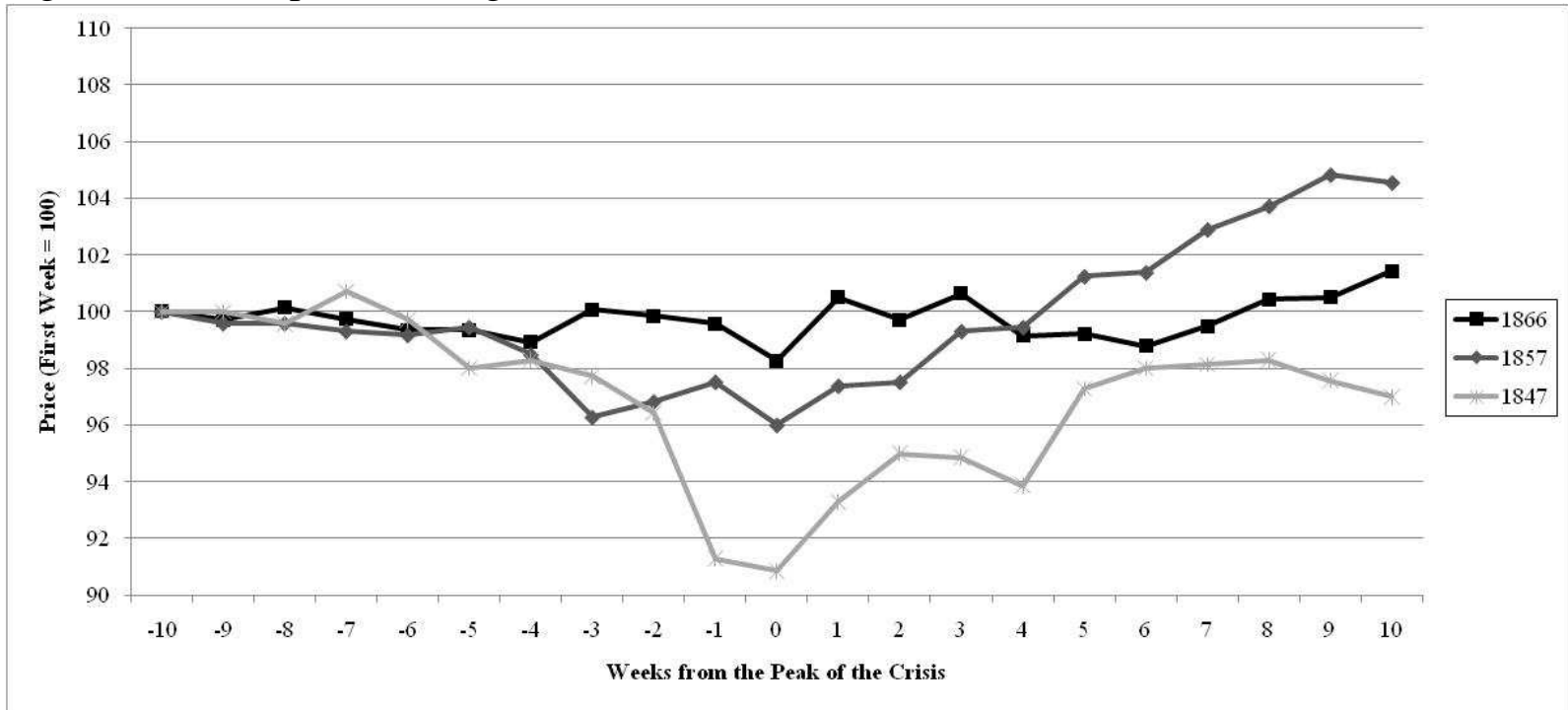

Source: Authors, from The Economist. Note: Peak of the crisis: week before Peel's Act suspension. 
Figure 7. Delinquent accounts and amounts in London, 1814-1914.

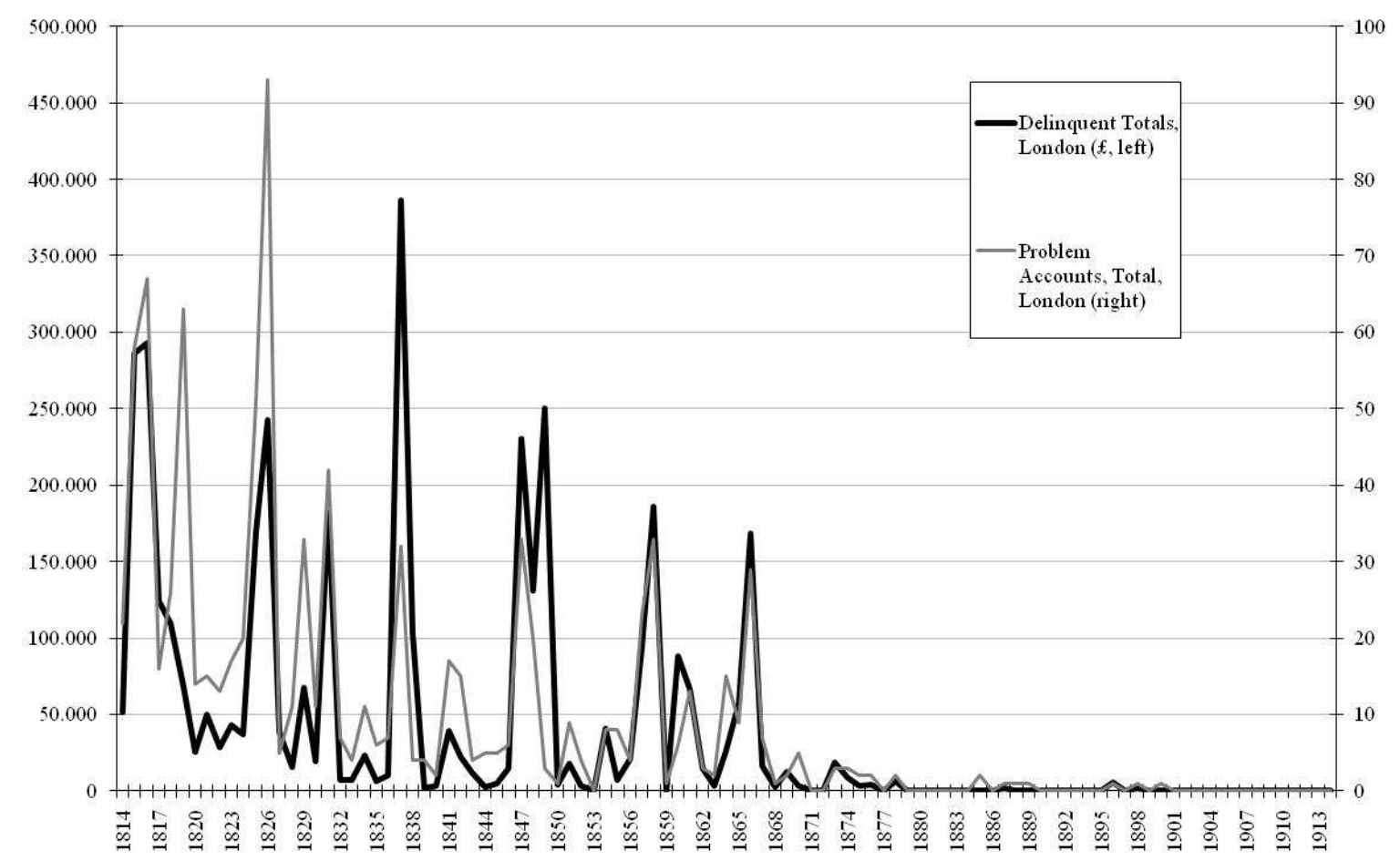

Source: Bank of England Archive, C 34/4. 
Figure 8. Delinquent amounts: London and Branches (\% of total discounts), 1844-1914.

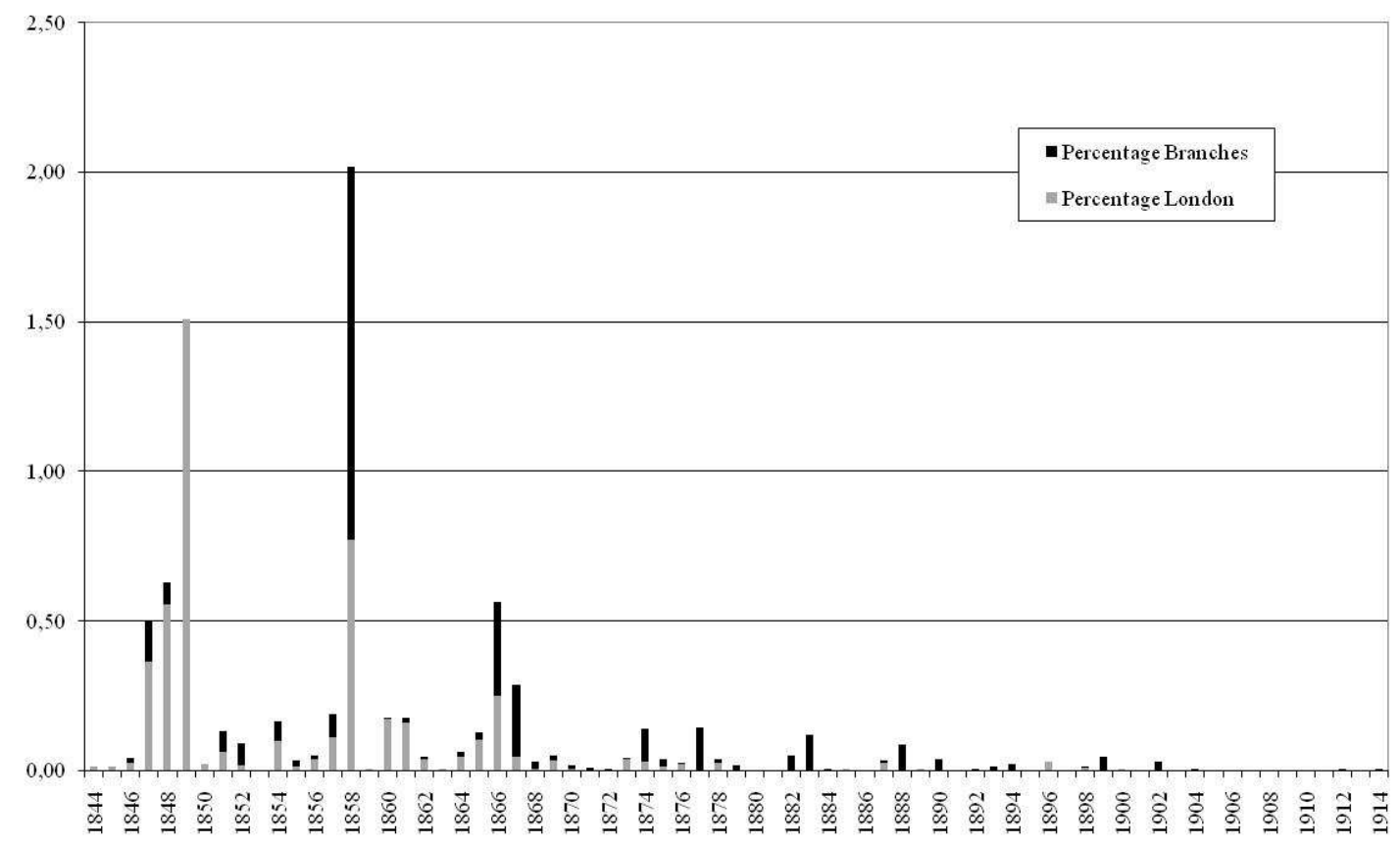

Source: Bank of England Archive, C 30/3, C 33/5, C 34/4, and C 34/5. 
Figure 9. Amounts at risk (Unpaid bills as \% of discounted bills), 1842-1914.

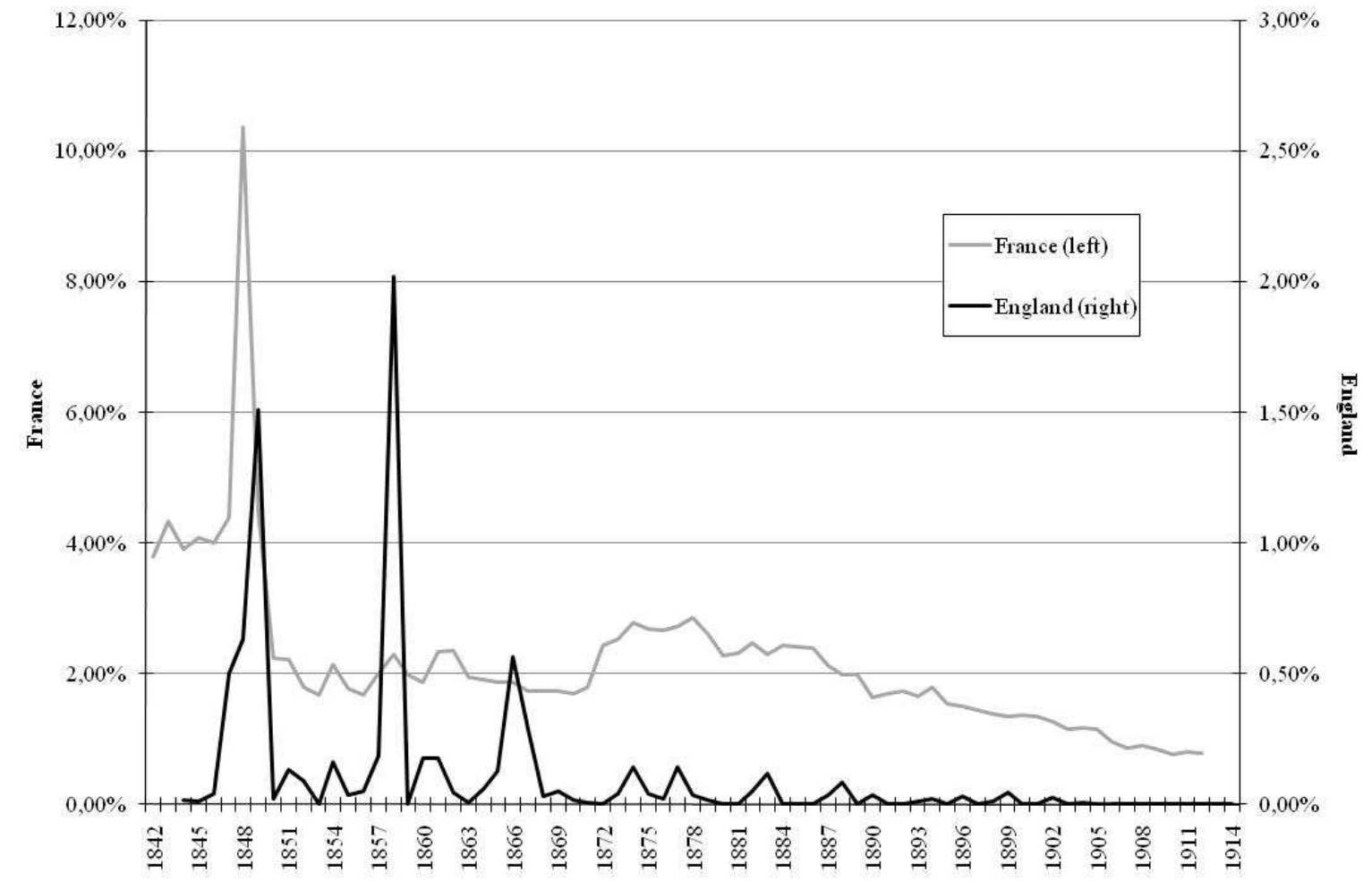

Source: Authors, from same sources as in Figures 7 and 8 (England) and Roulleau, Les règlements (France). 
Figure 10. The high rates during three crises.

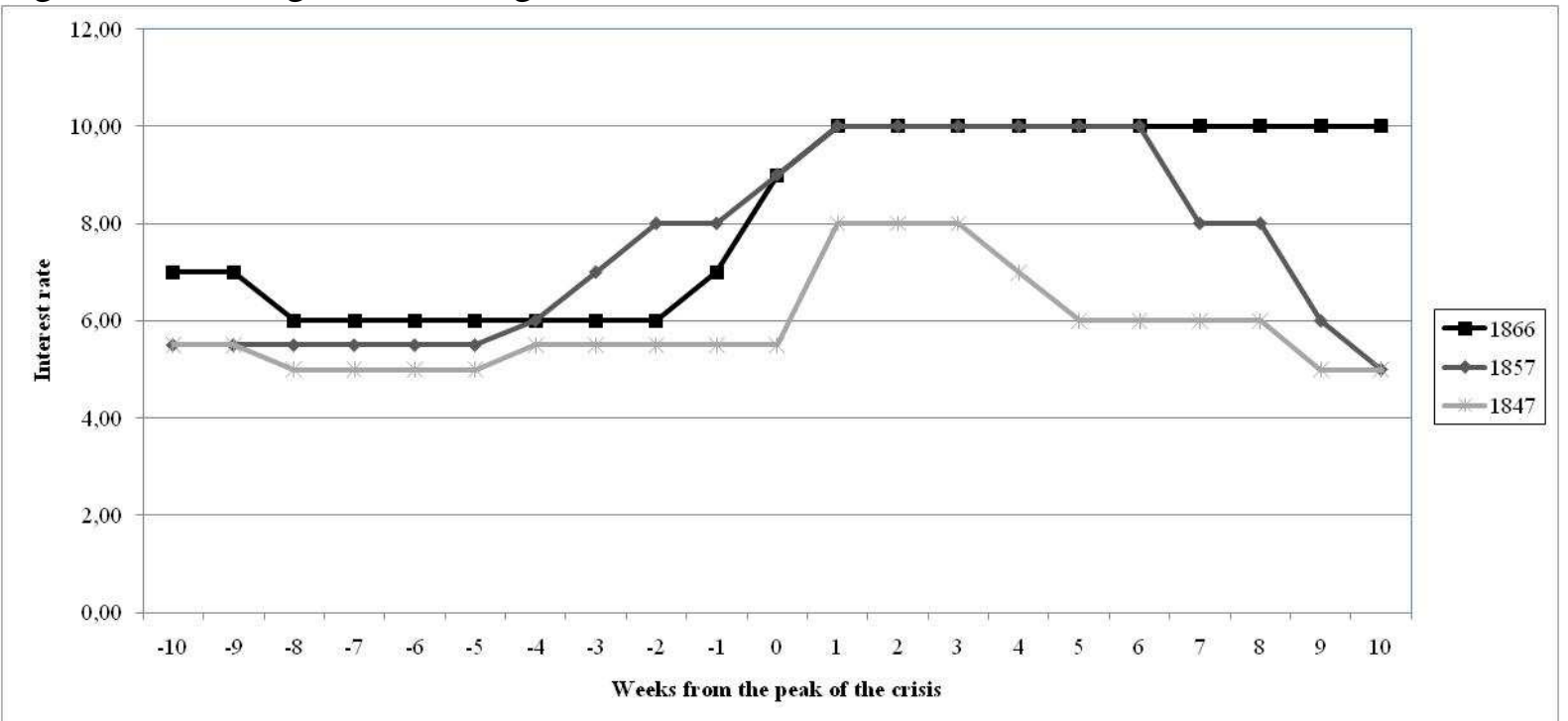

Source: Authors, from The Economist. 